\title{
Size-structured piscivory: advection and the linkage between predator and prey recruitment in young-of-the-year bluefish
}

\author{
Francis Juanes*, David O. Conover \\ Marine Sciences Research Center, State University of New York, Stony Brook, New York 11794-5000, USA
}

\begin{abstract}
The interaction of size-structured predator and prey populations can affect the recruitment success of both predators and prey. Here, we examine how the timing and location of spawning, advective processes, and size-structured predator-prey interactions may influence the ecology and life history of an offshore-spawning, estuarine-dependent marine fish. Bluefish Pomatomus saltatrix recruit to mid-Atlantic Bight estuaries as 2 distinct cohorts. The predominant spring-spawned cohort results from: (1) spawning in the South Atlantic Bight in March and April, (2) advection northward along the edges of the Gulf Stream, and (3) an active migration into New York/New Jersey (LSA) estuaries in June and July. A second less abundant cohort resulting from summer-spawning in the mid-Atlantic Bight recruits to inshore areas in August. This inshore recruitment entails a dramatic habitat shift that coincides with a feeding shift from planktivory to piscivory and a large increase in growth rates. We hypothesized that the migration of spring-spawned young-of-the-year (YOY) bluefish into northern estuaries at an advanced size facilitates piscivory on the local inshore fishes that become their principal prey. We tested this hypothesis by determining the annual recruitment date of YOY bluefish and their prey, and by examining the diet and prey size selectivities, and predator size-prey size relationships of YOY bluefish in Great South Bay (GSB), New York. Our results showed that: (1) the date of juvenile recruitment into GSB coincides with the appearance of their main prey item, Atlantic silversides Menidia menidia; (2) YOY bluefish feed primarily on the most abundant prey available in GSB; and (3) bluefish are size-selective, consistently ingesting small prey sizes. These results suggest that advection into high latitudes permits spring-spawned bluefish to exploit habitats at an earlier time and at a larger size than would otherwise be possible. This unique strategy also allows bluefish to accelerate the onset of piscivory by timing their estuarine entry with the appearance of small coastal fishes. The relationships between bluefish and their prey are determined by a complex interplay between recruitment timing of both predator and prey, relative prey (size and type) abundances and predator selectivities. The observed pattern of spawning, advection and recruitment to nursery areas, which is common to other bluefish populations, may represent a reproductive strategy that maximizes growth and survival.
\end{abstract}

KEY WORDS: Advection - Bluefish - Piscivory - Predator-prey interaction - Recruitment - Reproductive strategy $\cdot$ Size structure

\section{INTRODUCTION}

Various studies in aquatic systems have shown that interactions between size-structured predator and prey populations are governed by size-dependent processes such as relative growth rates, prey size selectivity and the timing of ontogenetic shifts in habi-

\footnotetext{
- Present address: Department of Forestry and Wildlife Management, University of Massachusetts, Amherst, Massachusetts 01003-4210,USA.E-mail: juanes@forwild.umass.edu
}

tat and diet (Adams \& DeAngelis 1987, Kerfoot \& Sih 1987). Variations in these size-dependent processes can affect the recruitment success of both predators and their prey (Werner \& Gilliam 1984, Ebenman \& Persson 1988, Reimchen 1990, Crowder et al. 1992). Werner \& Gilliam (1984) proposed that the timing of ontogenetic shifts maximizes fitness by minimizing the ratio of mortality over growth and can thus be viewed as being 'critical' to survival. The onset of piscivory in specialized piscivores has been shown to be one such critical period. For example, variability in 
the timing of the shift with prey size availability can lead to drastic changes in predator survival and future recruitment (Adams \& DeAngelis 1987, Wicker \& Johnson 1987, Bettoli et al. 1992, Buijse \& Houthuijzen 1992).

Piscivorous fishes tend to be functionally able to consume other fishes early in development (Popova 1978. Keast 1985a, b) and generally experience a large increase in growth after the ontogenetic diet shift to piscine prey (Larkin et al. 1957, Wicker \& Johnson 1987. Stergiou \& Fourtouni 1991). Hence, an acceleration of the onset of piscivory may be strongly favoured by natural selection. Some species appear to have evolved specialized life history traits that facilitate an early shift to piscivory. Temperate freshwater piscivores, for example, become piscivorous at a relatively young age by being spawned in advance of, and thereby achieving a size advantage over, the young of their piscine prey (Keast 1985a).

In marine systems, the matching of the onset of piscivory with the abundance of appropriately-sized prey is likely to be influenced by large-scale advective forces (i.e. currents, eddies, and wind-driven flow). Offshore-spawning, estuarine-dependent (or 'estuarine-opportunist, ${ }^{\prime}$ see Lenanton \& Potter 1987), marine fish must depend both on large-scale advection and on more local-scale physical mechanisms (such as tidal currents) to transport them into estuarine nurseries (Weinstein 1988, Zijlstra 1988, Hovenkamp 1991). The dependency of many marine fish on physical transport mechanisms, coupled with an interest in the dynamics of juvenile fishes (de Lafontaine et al.
1992, Walters \& Juanes 1993), has led to the suggestion that offshore-spawning, estuarine-dependent, marine fishes may have been selected to spawn near a predictable advective force that ensured transport to juvenile nursery areas at the appopriate time (Checkley et al. 1988, Jennings \& Pawson 1992, Juanes et al. 1994).

The bluefish Pomatomus saltatrix is an offshorespawning, estuarine-dependent fish that is unique among temperate North American fishes in 2 respects. First, recruitment occurs at 2 distinct times: a springspawned cohort originating in the South Atlantic Bight (SAB) (Kendall \& Walford 1979, Collins \& Stender 1987. Shima 1990), and a summer-spawned cohort originating in the mid-Atlantic Bight (MAB) (Fig. 1) Spring-spawned fish are advected northwards in association with the Gulf Stream and move into New York/New Jersey (USA) estuaries in late May or early June at a size of 50 to $70 \mathrm{~mm}$ total length (TL) (Nyman \& Conover 1988, McBride \& Conover 1991). Summerspawned fish recruit to $\mathrm{MAB}$ estuaries in mid- to late August at a size of 40 to $60 \mathrm{~mm}$ TL (McBride \& Conover 1991). This movement inshore entails a dramatic habitat shift and coincides with an increase in growth rate (McBride \& Conover 1991) and with a feeding shift from planktivory to piscivory (Marks \& Conover 1993). All young-of -the-year (YOY) bluefish leave MAB estuaries in September/October as water temperatures drop below 15 to $20^{\circ} \mathrm{C}$ (Nyman \& Conover 1988, McBride \& Conover 1991). The second unique characteristic is that spring-spawned bluefish reach an unusually large size at age 1 (Table 1) and are the only

Table 1. Approximate back-calculated length ( $\mathrm{mm})$ at age 1 and dominant diet type during first year for bluefish, as compared with several other inshore fishes of the middle Atlantic region

\begin{tabular}{|c|c|c|c|}
\hline Species & Common name & Length at age 1 & Dominant diet type \\
\hline Pomatomus saltatrix & Bluefish & $230-260^{1}$ & Fish $^{14}$ \\
\hline Paralichthys dentatus & Summer flounder & $260^{2}$ & Fish $^{15}$ \\
\hline Cynoscion regalis & Weakfish & $180^{3}$ & Invertebrate ${ }^{16}$ \\
\hline Scophthalmus aquosus & Windowpane & $<180^{4}$ & Invertebrate ${ }^{17}$ \\
\hline Pollachius virens & Pollock & $130-180^{5}$ & Invertebrate \\
\hline Alosa sapidissima & American shad & $150^{6}$ & Invertebrate ${ }^{6}$ \\
\hline Tautoga onutis & Tautog & $140^{7}$ & Invertebrate ${ }^{5}$ \\
\hline Leiostomus xanthurus & Spot & $140^{8}$ & Invertebrate $^{16}$ \\
\hline Prionotus carolinus & Northern searobin & $125^{9}$ & Invertebrate $^{9}$ \\
\hline Prionotus evolans & Striped searobin & $125^{9}$ & Invertebrate ${ }^{9}$ \\
\hline Morone saxatilis & Striped bass & $100-140^{10}$ & Invertebrate ${ }^{18}$ \\
\hline Merluccius bilinearis & Silver hake & $110^{11}$ & Invertebrate ${ }^{5}$ \\
\hline Stenotomus chrysops & Scup & $100^{12}$ & Invertebrate ${ }^{5}$ \\
\hline Peprilus triacanthus & Butterfish & $90^{13}$ & Invertebrate ${ }^{19}$ \\
\hline Centropristis striata & Black sea bass & $90^{5}$ & Invertebrate $^{5}$ \\
\hline
\end{tabular}


fish in temperate North America to enter the recreational fishery as young-of-the-year (i.e. at about $120 \mathrm{~d})$.

We hypothesize that the unusually large size attained by spring-spawned YOY bluefish at age 1 is a consequence of being spawned earlier at a lower latitude and of being advected to a higher latitude in association with a warm water mass (the Gulf Stream). Bluefish thereby get a head-start on the growing season and gain a predatory size advantage over the local inshore fishes that become their principal prey. This strategy may also permit bluefish to accelerate the onset of piscivory by matching the habitat shift to the recruitment of appropriate-sized prey that maximize foraging efficiency (Juanes et al. 1994). The objective of this study is to compare the patterns and timing of recruitment of YOY bluefish and their prey, and to quantify prey type and size preferences. In particular, we focus on the comparison between spring- and summer-spawned YOY bluefish diets. The temporal separation between the recruitment of distinct cohorts of similarly-sized spring- and summer-spawned individuals provides a unique opportunity to examine how cohort-specific size-structured interactions are influenced by recruitment timing, relative prey (size and type) abundance, prey life history, and predator selectivities.

\section{METHODS}

Field sampling. The main study site was located in Great South Bay (GSB), a shallow temperate estuary on the south shore of Long Island, New York $\left(40^{\circ}\right.$ $10^{\prime} \mathrm{N}, 73^{\circ} 10^{\prime} \mathrm{W}$ ) (Fig. 1). The bay has an average depth of $1.5 \mathrm{~m}$, although depths of up to $7 \mathrm{~m}$ occur in navigation channels. The bottom is typically sand/ mud, and eelgrass beds Zostera marina develop along the shoreline during spring and summer. Four stations within the bay, ranging from Smith Point Park on the easternmost end to Seatuck on the westernmost end (see McBride 1989 for specific station locations), were sampled to obtain fish for gut content analyses and to assess relative predator and prey recruitment dates. Collections were made with a $30 \times 2 \mathrm{~m}$ beach seine (6 $\mathrm{mm}$ mesh in the wings, $3 \mathrm{~mm}$ mesh bag) approximately biweekly from May until October 1988, 1989, and 1990. Three successive hauls were completed at each station. The net was set from shore by wading to a depth of about $1 \mathrm{~m}$ with one end of the net, and sweeping the other end of the net through as wide an arc as possible. All fish collected were sorted by species and enumerated. Two species of shrimp (sand shrimp Crangon septemspinosa and grass shrimp Palaemonetes spp.) were also enumerated in 1990.

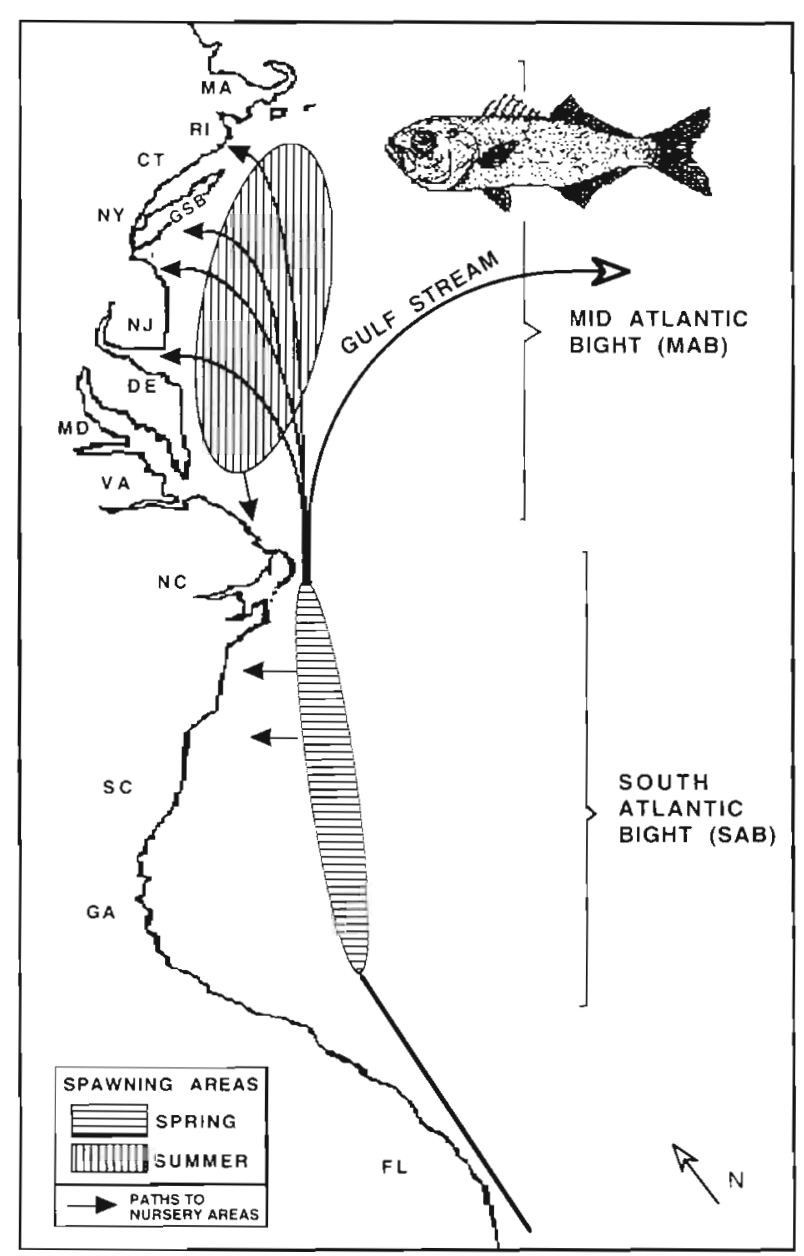

Fig. 1. Sketch map of the east coast of the US, modified from Kendall \& Walford (1979), showing coastal states and locations of South Atlantic Bight (SAB), mid-Atlantic Bight (MAB), Gulf Stream, and Great South Bay (GSB) on the south shore of Long Island, New York. Spawning areas are taken from Kendall \& Walford (1979). Juvenile recruitment areas are taken from Nyman \& Conover (1988), McBride \& Conover (1991) and McBride et al. (1993)

These 2 species of shrimp were not differentiated for any of the analyses in this study and are referred to throughout by the common name of 'shrimp'. All bluefish and subsamples of the other contents of the net (potential prey) were collected, kept on ice and frozen upon return to the lab.

Temperature and salinity measurements were taken just below the surface at each station. Temperature data over the summer in GSB followed a typical curve with maximum temperatures observed in July and August $\left(\sim 28^{\circ} \mathrm{C}\right)$ and minimum temperatures in early June and October $\left(\sim 15^{\circ} \mathrm{C}\right)$. Salinities ranged from 15 to $28 \%$ and marginally increased towards late summer (Juanes 1992).

Predator-prey recruitment. Relative abundances of bluefish and their main prey items were calculated as 
the mean number of animals caught per seine haul (catch per unit effort, CPUE). Spring- and summerspawned YOY bluefish CPUEs were compared to the CPUEs of their main prey items to assess relative recruitment dates and peaks in abundance. Similar comparisons were performed for YOY bluefish CPUE and shrimp CPUE for 1990 (the only year for which shrimp relative abundances were available), and for YOY bluefish CPUE and Atlantic silverside Menidia menidia CPUE for 1987 (data obtained from McBride 1989).

Diet. Bluefish were thawed, measured for total length (TL) and their stomachs extracted. Stomach contents of bluefish collected in 1988 and 1989 were identified to the lowest possible taxon, enumerated, blotted dry, weighed $( \pm 0.01 \mathrm{~g})$, and measured (TL, $\pm 1.0 \mathrm{~mm}$ ). Two indices were computed to describe diets (Hyslop 1980): (1) number of stomachs in which a taxon occurred, expressed as a percentage of the total number of stomachs containing food $(\% \mathrm{~F}=$ percent frequency of occurrence), and (2) weight of a taxon, expressed as a percentage of the total weight of food items $(\% \mathrm{~W}=$ percent weight $)$.

Bluefish were grouped by cohort (spring- or summer-spawned) and size class to assess ontogenetic diet shifts. Spring-spawned fish were categorized into 5 length groups: $<90,90-119,120-149,150-180$, and $>180 \mathrm{~mm}$ TL, and summer-spawned individuals were categorized as either $<90$ or $>90 \mathrm{~mm}$ TL. The summerspawned individuals were easily detectable by the appearance of much smaller fish (e.g. 50 vs $150 \mathrm{~mm}$ TL) in length frequency distributions starting in midAugust (Kendall \& Walford 1979, Nyman \& Conover 1988, McBride \& Conover 1991, Juanes et al. 1993).

Predator-size prey-size relationships. The relationships between ingested prey size (total length for fish, shrimp and zoea) and predator size (TL) were determined by regression analysis. Analysis of covariance was used to determine differences between prey species (Atlantic silversides vs bay anchovies Anchoa mitchilli vs shrimp) and bluefish cohorts (spring-vs summer-spawned). Because data were not always normal (as measured using the Kolomogorov-Smirnov test) or had heterogeneous variances (as measured by Bartlett's test), all regressions and ANCOVAs were also computed using $\log _{10}$ transformed data. We report the results obtained using untransformed data because comparisons made using log-transformed data provided similar results in all cases, and these transformed data were also not always normal or homoscedastic

Predator mouth gape and prey body width. Ontogenetic diet shifts in fishes are often characterized by abrupt changes in morphology. For example, increases in mouth gape often accompany shifts to larger prey sizes. Hambright (1991) suggested that body depth may be a more useful measure of prey size than the traditional measure of prey length when examining gape limitation and prey size selection of piscivorous fishes. To assess potential bluefish gape limitation, bluefish gape-at-length was compared to prey body widths by contrasting regressions between bluefish total length and mouth gape (MG, measured as the distance between the top and the bottom of the mouth when open) to regressions between total length and maximum body width (BW) for the 2 main piscine prey species: Atlantic silverside and bay anchovy. The extent of gape limitation in field-collected bluefish was then assessed by first converting consumed (i.e. from the gut content analyses) Atlantic silverside and bay anchovy prey lengths to body widths (using the above regressions between total length and maximum body width), and then comparing these 'original' prey body widths to bluefish mouth gape.

Prey-size selection. Subsamples from the field collections of potential prey were thawed, and identified to species in the laboratory. Prey lengths $( \pm 0.1 \mathrm{~mm}$ TL) of each of the 3 main prey types (see 'Results') from each sampling date were measured to obtain length frequencies at each date. Prey length frequencies for all stations for each date were combined for the analysis. To assess prey size selection, the field length frequency distributions of each species for each date were compared to length frequency distributions of prey individuals obtained from the guts of bluefish collected on those same dates. For those dates on which more than 10 measurable prey items were found in the guts of the bluefish collected on that date, a KolmogorovSmirnov 2 sample test was used to compare the length frequency distributions of items in the gut and in the field. A Mann-Whitney $U$-test compared the rank sums computed from these data, while a median test (Zar 1984) compared their medians.

\section{RESULTS}

\section{Predator-prey recruitment}

The recruitment (defined as the first appearance in our beach seine) of spring-spawned bluefish in Great South Bay occurred just after the appearance of juvenile Menidia menidia in each of the years 1987 through 1990 (Fig. 2A-D). The peak in bluefish abundance occurred 1 to $2 \mathrm{wk}$ after the peak in abundance of $M$. menidia. Peak bluefish CPUE ranged from 5.4 to 7.1 YOY per seine haul. Peak $M$. menidia CPUE ranged from 350 to 500 juveniles per haul except for 1987 where the peak occurred at about 100 juveniles per haul. These peaks in abundance were followed by steady declines in relative numbers of bluefish and 


\section{Spring-spawned bluefish}
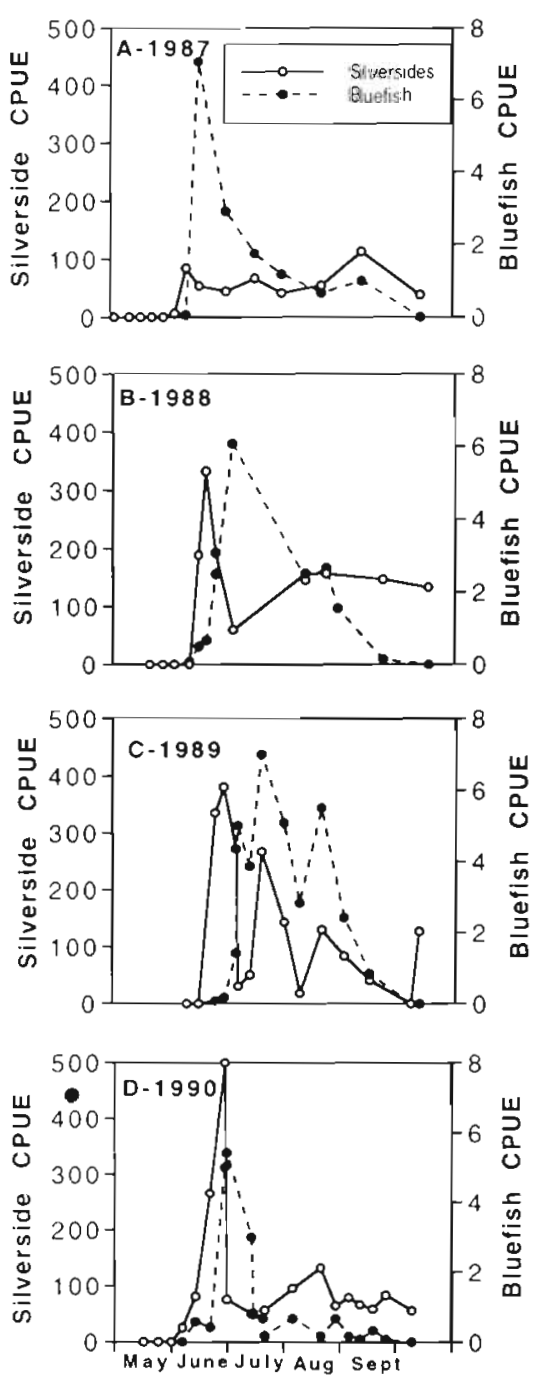

DATE

\section{Summer-spawned bluefish}
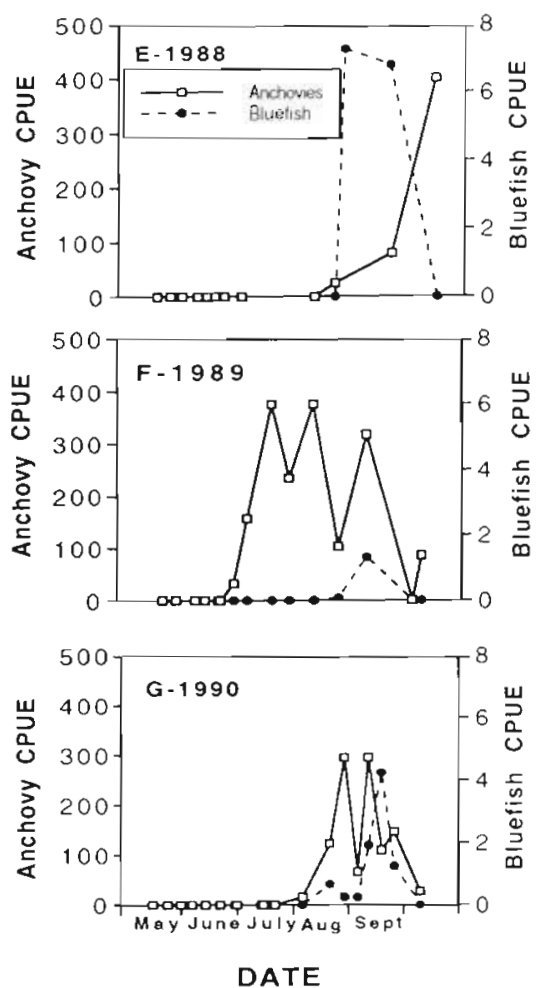

Fig, 2. (A-D) Comparison of spring-spawned bluefish catch-per-uniteffort (CPUE) versus CPUE of their main prey item (juvenile Atlantic silverside Menidia menidia) in Great South Bay for 1987 to 1990. The 1987 data are from McBride (1989). (E-G) Comparison of summerspawned bluefish CPUE versus CPUE of their main prey item (juvenile bay anchovy Anchoa mitchilli) in Great South Bay for 1988 to 1990. For all species, CPUE was measured as the mean number of fish per haul
Atlantic silversides through the rest of the sampling season. No relationship between peaks of abundance of spring-spawned bluefish and shrimp abundances were obvious in the 1 year where shrimp abundance data were available (Juanes 1992).

Summer-spawned bluefish appeared in GSB during late August and early September each year (Fig. 2E-G). In 1989 and 1990, they recruited after bay anchovies were already abundant (Fig. 2E-G). Peak abundance of summer-spawned bluefish was more variable (1.3 to 7.3 per haul) than those of spring-spawned bluefish. Bay anchovies also exhibited wide fluctuations in their relative abundances and time of recruitment.

Overall, Atlantic silversides and bay anchovies dominated numerically the fish assemblage in GSB, consistently representing over $50 \%$ of the individuals collected on any date (Fig. 3). In 1990, when shrimp were also enumerated, they generally represented a small proportion of the total macrofaunal community.

\section{Diet}

A total of 841 fish were examined for gut contents in 1988 and 1989. Overall, about 60 to $70 \%$ of the diet by weight was composed of fishes. The highest levels of piscivory were found in the smallest bluefish sizes and in summer-spawned fish (>99\% fish by weight, Fig. 4). The diet was dominated by 3 main groups: Menidia menidia, Anchoa mitchilli, and shrimp (Crangon septemspinosa and Palaemonetes spp.). The relative importance of these items in the diet varied from year to year (Tables 2 to 4, Fig. 4). Both indices (frequency of occurrence and weight) gave similar overall 


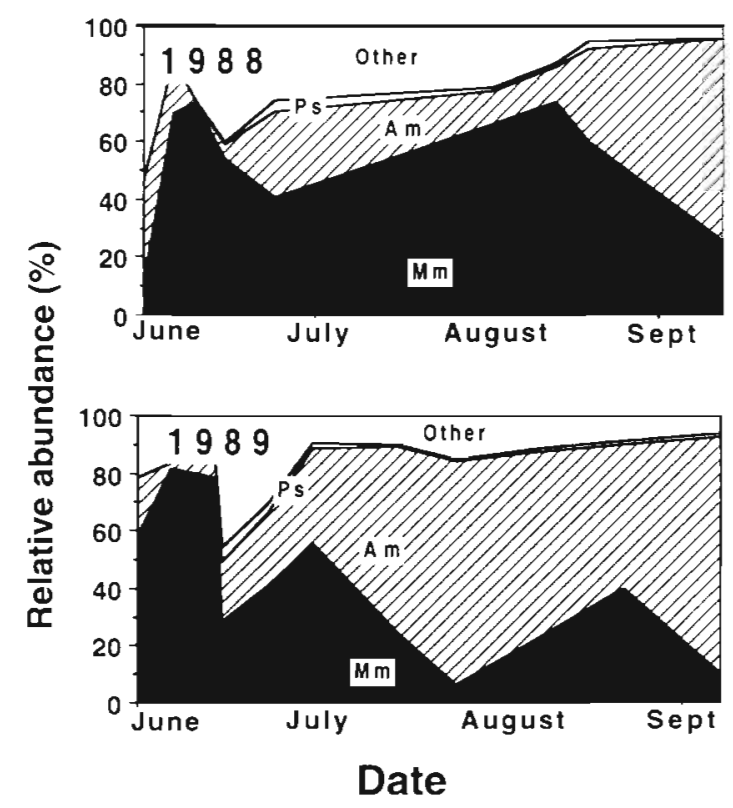

results with the exception of the categories representing unidentified fish and shrimp remains. These categories tended to be larger as percentage frequency, because they occurred in many stomachs, but were usually not a major part of the gut contents by weight. Overall, about $20 \%$ of the stomachs analyzed were empty.

\section{9}

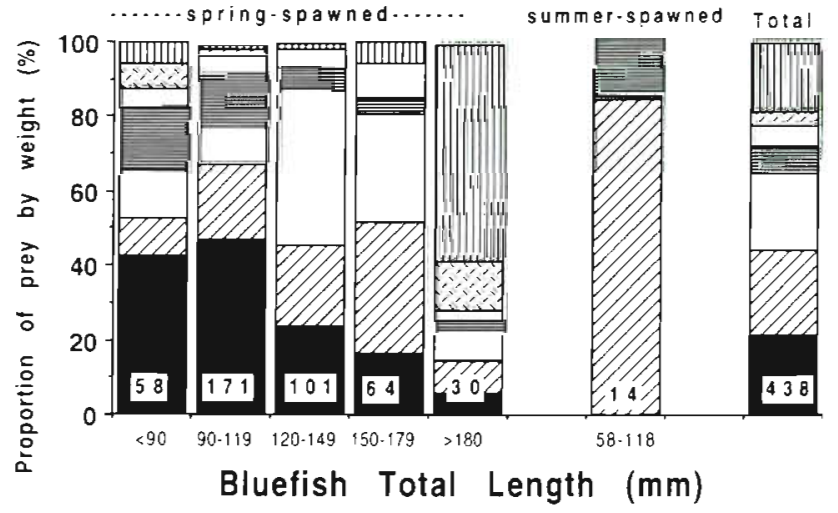

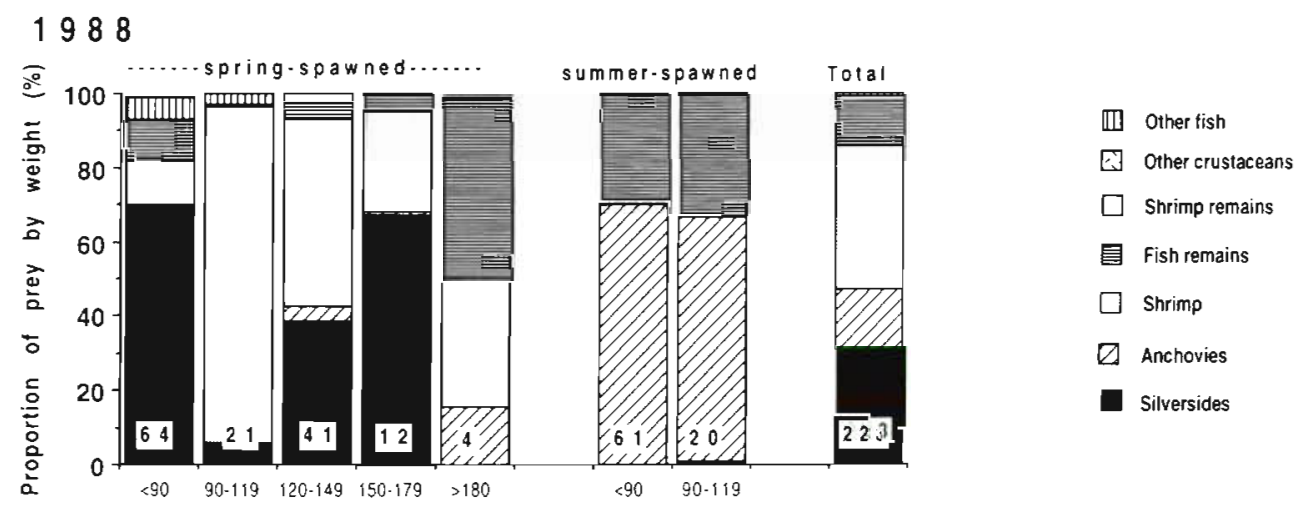

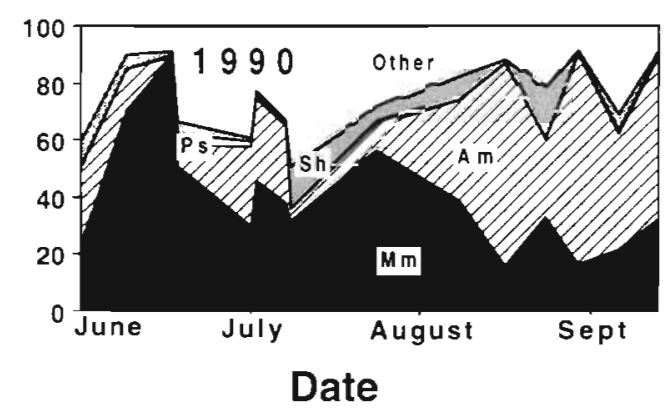

Fig. 3. Percentage of the Great South Bay fish community in 1988, 1989, and 1990 represented by Atlantic silversides ('Mm'), bay anchovies ('Am'), bluefish (both spring- and summer-spawned. 'Ps'), and other fishes ('Other'). In 1988 and 1989 only fish species were enumerated. In 1990, shrimp (grass and sand shrimp. 'Sh') were also counted

Different patterns emerged when analyzing the results by size, by bluefish cohort, and by year. For spring-spawned bluefish in 1988, Menidia menidia was the predominant prey type in the small and intermediate bluefish size categories $(<90,120-149$, and $150-180 \mathrm{~mm}$ ). Shrimp were the major component of the diet for fish 90-119 mm (although only 21 fish

Fig. 4. Proportion of prey (by weight) eaten by spring- and summer-spawned YOY bluefish by size category for 1.988 and 1989. Shrimp category includes grass and sand shrimp Palaemonetes spp. and Crangon septemspinosa respectively. Other crustaceans include zoea and crab remains. Other fish category includes threespine stickleback Gasterosteus aculeatus, northern pipefish Syngnathus fuscus. American eel Anguilla rostrata, rainwater killifish Lucania parva, killifish Fundulus spp., winter flounder Pleuronectes americanus, seatrout Cynoscion spp., northern puffer Sphoeroides maculatus, permit Trachinotus falcatus, fish eggs, and unknown fish species. Numbers within columns are sample sizes 
Table 2. Stomach contents of spring-spawned juvenile bluefish by size category (in $\mathrm{mm}$ TL) collected in Great South Bay in 1988. \% F: percentage occurrence, \%W: percentage wet wt

\begin{tabular}{|c|c|c|c|c|c|c|c|c|c|c|c|c|c|}
\hline \multicolumn{2}{|c|}{ Prey type } & \multicolumn{12}{|c|}{ Bluefish size (mm TL) } \\
\hline \multirow[t]{2}{*}{ Species } & \multirow{2}{*}{$\begin{array}{l}\text { Common } \\
\text { name }\end{array}$} & \multicolumn{2}{|c|}{$<90$} & \multicolumn{2}{|c|}{90 to 119} & \multicolumn{2}{|c|}{120 to 149} & \multicolumn{2}{|c|}{150 to 180} & \multicolumn{2}{|c|}{$>180$} & \multicolumn{2}{|c|}{ Total } \\
\hline & & $\% \mathrm{~F}$ & $\% W$ & $\% \mathrm{~F}$ & $\% \mathrm{~W}$ & $\% \mathrm{~F}$ & $\% \mathrm{~W}$ & $\% \mathrm{~F}$ & $\% \mathrm{~W}$ & $\% \mathrm{~F}$ & $\% W$ & $\% \mathrm{~F}$ & $\% \mathrm{~W}$ \\
\hline Menidia menidia & $\begin{array}{l}\text { Atlantic } \\
\text { silverside }\end{array}$ & 54.69 & 70.24 & 9.52 & 5.95 & 17.07 & 38.67 & 25.00 & 67.23 & & & 33.10 & 38.44 \\
\hline Anchoa mitchilli & Bay anchovy & & & & & 2.43 & 4.21 & 8.33 & 0.85 & 25.00 & 15.51 & 2.11 & 2.87 \\
\hline $\begin{array}{l}\text { Crangon sp. and } \\
\text { Palaemonetes sp. }\end{array}$ & $\begin{array}{l}\text { Sand and grass } \\
\text { shrimp }\end{array}$ & 24.24 & 11.51 & 66.67 & 90.44 & 46.34 & 50.15 & 33.33 & 26.90 & 50.00 & 34.21 & 38.73 & 49.53 \\
\hline $\begin{array}{l}\text { Unidentified } \\
\text { fish remains }\end{array}$ & & 21.21 & 11.50 & & & 31.71 & 4.44 & 33.33 & 4.79 & 75.00 & 49.41 & 23.94 & 6.34 \\
\hline $\begin{array}{l}\text { Unidentified } \\
\text { shrimp remains }\end{array}$ & & 1.51 & 0.79 & 14.28 & 0.68 & 9.76 & 2.52 & & & & & 5.63 & 1.47 \\
\hline Fish eggs & & 3.12 & 1.36 & & & & & & & & & 1.41 & 0.16 \\
\hline $\begin{array}{l}\text { Gasterosteus } \\
\text { aculeatus }\end{array}$ & $\begin{array}{l}\text { Threespine } \\
\text { stickleback }\end{array}$ & 3.12 & 4.60 & & & & & & & & & 1.41 & 0.54 \\
\hline $\begin{array}{l}\text { Syngnathus } \\
\text { fuscus }\end{array}$ & $\begin{array}{l}\text { Northern } \\
\text { pipefish }\end{array}$ & & & 4.76 & 0.84 & & & & & & & 0.70 & 0.17 \\
\hline $\begin{array}{l}\text { Anguilla } \\
\text { rostrata }\end{array}$ & $\begin{array}{l}\text { American } \\
\text { eel }\end{array}$ & & & 4.76 & 2.09 & & & & & & & 0.70 & 0.42 \\
\hline Other fish total & & 6.25 & 5.95 & 9.52 & 2.93 & & & & & & & 4.22 & 1.28 \\
\hline Eelgrass & & & & & & & & 8.30 & 0.24 & 25.00 & 0.87 & 1.41 & 0.07 \\
\hline Total fish & & 85.94 & 87.70 & 19.05 & 8.88 & 48.78 & 47.33 & 66.70 & 72.86 & 100 & 64.92 & 64.08 & 48.92 \\
\hline Total stomachs an & alyzed & & 83 & 26 & & & 19 & & 3 & 5 & 5 & 17 & 76 \\
\hline Number containin & g prey & & 64 & 21 & & & 1 & & 2 & 4 & 4 & 142 & 12 \\
\hline Dates bluefish wer & re collected (1988) & $\begin{array}{l}\mathrm{Ju} \\
\text { to } \mathrm{J}\end{array}$ & $\begin{array}{l}\text { nn } 8 \\
\text { Jul } 1\end{array}$ & $\begin{array}{r}\mathrm{Jul} \\
\text { to } \mathrm{Au}\end{array}$ & $\begin{array}{l}\operatorname{lig} 25 \\
\lg 25\end{array}$ & $\begin{array}{r}\mathrm{Au} \\
\text { to } \mathrm{Al}\end{array}$ & $\begin{array}{l}\lg 8 \\
\operatorname{ug} 25\end{array}$ & $\begin{array}{r}\mathrm{Au} \\
\text { to } \mathrm{Se}\end{array}$ & $\begin{array}{l}\lg 8 \\
\operatorname{ep} 17\end{array}$ & $\begin{array}{l}\text { Aug } \\
\text { to Se }\end{array}$ & $\begin{array}{l}\operatorname{g} 25 \\
\operatorname{ep} 29\end{array}$ & & \\
\hline
\end{tabular}

constituted this sample from 2 sampling dates) and tended to become less abundant as bluefish size increased. Anchoa mitchilli were relatively unimportant (Table 2, Fig. 4). In 1989 spring-spawned bluefish, $M$. menidia dominated the diet of the 2 smallest size categories and then decreased in relative importance with increasing bluefish size (Table 3, Fig. 4). Shrimp tended to be less abundant in the diet in 1989 than in 1988 and were present mostly in the diet of intermediate-size bluefish (120-180 mm). Bay anchovies tended to be more important in 1989 than in 1988 with the largest proportions found in intermediate-sized fish $(120-179 \mathrm{~mm})$. The diets of the largest bluefish (>180 mm) were dominated by the 'other fish' category composed mainly of winter flounder Pleuronectes americanus. Overall, the 1989 diet appeared to be more diverse than in 1988 , with more prey categories per size class, although this may have been a function of the larger sample sizes in 1989 (Tables 2 \& 3, Fig. 4).

The diet of summer-spawned bluefish in contrast was almost completely dominated by bay anchovies. Because the only other major part of the diet of these fish was the 'fish remains' category, likely to be largely bay anchovy, almost $100 \%$ of the diet probably consisted of Anchoa mitchilli (Table 4, Fig. 4).

\section{Predator-size prey-size relationships}

\section{Overall}

There was an overall positive linear relationship between prey size and predator size when all prey were included $\left(r^{2}=0.215, p<0.001, n=376\right)$. When examining only fish prey, the predictive strength of the relationship increased slightly (Fig. 5).

By prey species

Different patterns emerged when comparing predator-prey relationships among the main prey items and bluefish cohorts (Fig. 6). For these analyses, the data for both years were combined in order to obtain complete ranges of bluefish sizes. The regression of Meni- 
Table 3. Stomach contents of spring-spawned juvenile bluefish by size category (in mm TL) collected in Great South Bay in 1989. \%F: percentage occurrence, \%W: percentage wet wt

\begin{tabular}{|c|c|c|c|c|c|c|c|c|c|c|c|c|c|}
\hline \multicolumn{2}{|c|}{ Prey type } & \multicolumn{12}{|c|}{ Bluefish size (mm TL) } \\
\hline \multirow[t]{2}{*}{ Species } & \multirow{2}{*}{$\begin{array}{l}\text { Common } \\
\text { name }\end{array}$} & \multicolumn{2}{|c|}{$<90$} & \multicolumn{2}{|c|}{90 to 119} & \multicolumn{2}{|c|}{120 to 149} & \multicolumn{2}{|c|}{150 to 180} & \multicolumn{2}{|c|}{$>180$} & \multicolumn{2}{|c|}{ Total } \\
\hline & & $\% \mathrm{~F}$ & $\% \mathrm{~W}$ & $\% \mathrm{~F}$ & $\% W$ & $\% \mathrm{~F}$ & $\% W$ & $\% \mathrm{~F}$ & $\% \mathrm{~W}$ & $\% F$ & $\% W$ & $\% \mathrm{~F}$ & $\% \mathrm{~W}$ \\
\hline Menidia menidia & $\begin{array}{l}\text { Atlantic } \\
\text { silverside }\end{array}$ & 25.86 & 42.37 & 40.94 & 46.93 & 23.76 & 23.48 & 14.06 & 16.62 & 10.00 & 5.84 & 28.54 & 22.29 \\
\hline Anchoa mitchilli & Bay anchovy & 5.17 & 10.45 & 22.22 & 20.51 & 30.69 & 22.16 & 26.56 & 35.12 & 16.67 & 8.44 & 22.17 & 19.96 \\
\hline $\begin{array}{l}\text { Crangon sp. \& } \\
\text { Palaemonetes sp. }\end{array}$ & $\begin{array}{l}\text { Sand \& grass } \\
\text { shrimp }\end{array}$ & 6.89 & 12.25 & 10.53 & 9.89 & 45.54 & 41.62 & 31.25 & 28.93 & 33.33 & 7.72 & 23.11 & 21.73 \\
\hline \multicolumn{2}{|c|}{ Unidentified fish remains } & 41.38 & 16.89 & 29.24 & 14.10 & 18.81 & 5.41 & 23.44 & 4.69 & 13.33 & 3.13 & 26.41 & 6.73 \\
\hline \multicolumn{2}{|c|}{ Unidentified shrimp remains } & 13.79 & 5.72 & 14.62 & 5.13 & 14.85 & 5.55 & 26.56 & 8.81 & 10.00 & 2.91 & 16.04 & 5.34 \\
\hline \multicolumn{2}{|l|}{ Zoea } & 22.41 & 6.63 & 7.01 & 2.07 & & & & & & & 5.90 & 0.64 \\
\hline \multicolumn{2}{|l|}{ Crab remains } & & & & & & & & & 6.67 & 12.90 & 0.47 & 3.80 \\
\hline \multicolumn{2}{|c|}{ Other crustaceans total } & 22.41 & 6.63 & 7.01 & 2.07 & & & & & 6.67 & 12.90 & 6.37 & 4.44 \\
\hline \multicolumn{2}{|l|}{ Fish eggs } & 1.72 & 0.05 & & & & & & & & & 0.25 & 0.00 \\
\hline \multicolumn{2}{|l|}{ Unknown fish spp. } & & & 1.17 & 1.03 & & & 3.12 & 5.19 & 3.33 & 0.26 & 1.18 & 1.31 \\
\hline Lucania parva & $\begin{array}{l}\text { Rainwater } \\
\text { killifish }\end{array}$ & 1.72 & 5.63 & & & & & & & & & 0.25 & 0.18 \\
\hline Fundulus spp. & Killifish & & & & & 0.99 & 0.20 & & & & & 0.25 & 0.05 \\
\hline $\begin{array}{l}\text { Pleuronectes } \\
\text { americanus }\end{array}$ & $\begin{array}{l}\text { Winter } \\
\text { flounder }\end{array}$ & & & & & 0.99 & 1.37 & & & 26.67 & 36.44 & 2.12 & 11.11 \\
\hline $\begin{array}{l}\text { Gasterosteus } \\
\text { aculeatus }\end{array}$ & $\begin{array}{l}\text { Threespine } \\
\text { stickleback }\end{array}$ & & & & & & & 1.56 & 0.63 & & & 0.25 & 0.12 \\
\hline $\begin{array}{l}\text { Syngnathus } \\
\text { fuscus }\end{array}$ & $\begin{array}{l}\text { Northern } \\
\text { pipefish }\end{array}$ & & & & & & & & & 6.67 & 1.42 & 0.47 & 0.42 \\
\hline Cynoscion spp. & Seatrout & & & & & & & & & 3.33 & 14.05 & 0.23 & 4.14 \\
\hline $\begin{array}{l}\text { Sphoeroides } \\
\text { falcatus }\end{array}$ & $\begin{array}{l}\text { Northern } \\
\text { puffer }\end{array}$ & & & & & & & & & 3.33 & 5.65 & 0.23 & 1.67 \\
\hline $\begin{array}{l}\text { Trachinotus } \\
\text { carolinus }\end{array}$ & Permit & & & & & & & & & 3.33 & 0.25 & 0.25 & 0.07 \\
\hline Other fish total & & 3.44 & 5.68 & 1.17 & 1.03 & 1.98 & 1.57 & 4.68 & 5.82 & 46.66 & 58.09 & 5.48 & 19.09 \\
\hline Eelgrass & & & & 0.58 & 0.33 & 1.98 & 0.22 & & & 6.67 & 0.98 & 1.18 & 0.42 \\
\hline Total fish & & 65.52 & 75.40 & 85.38 & 82.57 & 69.31 & 52.62 & 62.50 & 62.25 & 80.00 & 75.49 & 75.00 & 67.95 \\
\hline Total stomachs ana & lyzed & & 4 & 23 & & & 24 & 73 & & & 32 & 53 & 34 \\
\hline Number containing & prey & 5 & 8 & 17 & & & 01 & 64 & & & 30 & & 24 \\
\hline Dates bluefish were & collected (1989) & $\begin{array}{r}\mathrm{Ju} \\
\text { to } \mathrm{J}\end{array}$ & $\begin{array}{l}\text { n } 8 \\
\text { II } 26\end{array}$ & $\begin{array}{l}\text { Jun } \\
\text { to Al }\end{array}$ & $\begin{array}{c}20 \\
\lg 9\end{array}$ & $\begin{array}{l}\text { Jur } \\
\text { to Au }\end{array}$ & $\begin{array}{l}\text { n } 28 \\
\operatorname{ug} 22\end{array}$ & $\begin{array}{r}\mathrm{Jul} \\
\text { to Se }\end{array}$ & $\begin{array}{l}18 \\
\mathrm{p} 20\end{array}$ & $\begin{array}{r}\text { Jul } \\
\text { to } \mathrm{Se}\end{array}$ & $\begin{array}{l}126 \\
\text { ep } 20\end{array}$ & & \\
\hline
\end{tabular}

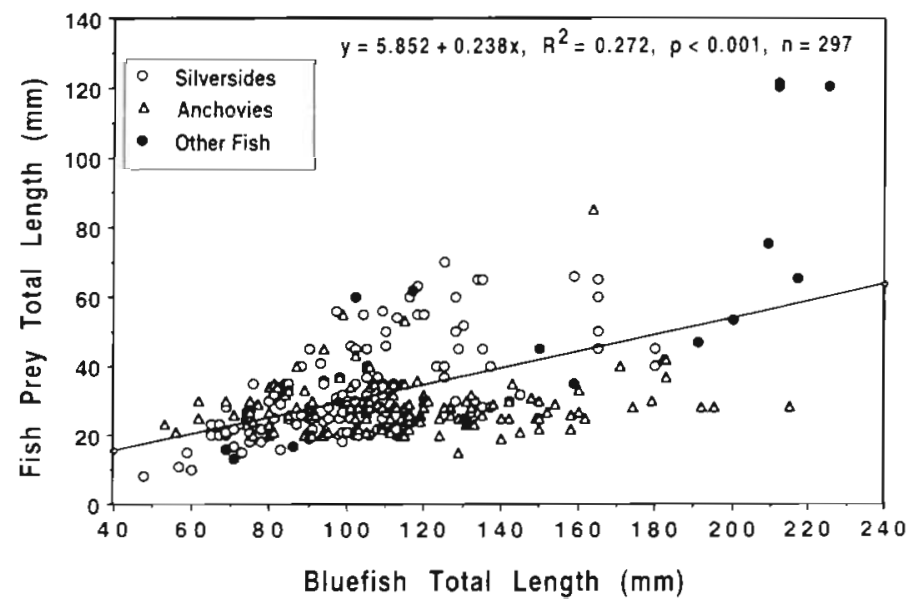

Fig. 5. Relationship between fish prey total length and spring-and summer-spawned bluefish total length. Other fish category includes northern pipefish. American eel, threespine stickleback, winter flounder, killifish, seatrout and 1 unknown fish 
Table 4. Stomach contents of summer-spawned juvenile bluefish by size category (in mm TL_) collected in Great South Bay in 1988 and 1989 . \% F percentage occurrence, \%W: percentage wet wt

\begin{tabular}{|c|c|c|c|c|c|c|c|c|c|c|c|c|c|}
\hline \multirow{2}{*}{\multicolumn{2}{|c|}{ Prey type }} & \multicolumn{12}{|c|}{ Bluefish size ( $\mathrm{mm}$ TL) } \\
\hline & & & & \multicolumn{2}{|c|}{1988} & & & & & & 989 & & \\
\hline \multirow[t]{2}{*}{ Species } & \multirow{2}{*}{$\begin{array}{l}\text { Common } \\
\text { name }\end{array}$} & \multicolumn{2}{|c|}{$<90$} & & 90 & \multicolumn{2}{|c|}{ Total } & \multicolumn{2}{|c|}{$<90$} & \multicolumn{2}{|c|}{$>90$} & \multicolumn{2}{|c|}{ Total } \\
\hline & & $\% \mathrm{~F}$ & $\% \mathrm{~W}$ & $\% \mathrm{~F}$ & $\% \mathrm{~W}$ & $\% \mathrm{~F}$ & $\% \mathrm{~W}$ & $\% \mathrm{~F}$ & $\% \mathrm{~W}$ & $\% \mathrm{~F}$ & $\% W$ & $\% F$ & $\% W$ \\
\hline Menidia menidia & $\begin{array}{l}\text { Atlantic } \\
\text { silverside }\end{array}$ & & & 5.00 & 2.89 & 1.10 & 1.13 & & & & & & \\
\hline Anchoa mitchilli & Bay anchovy & 49.29 & 70.17 & 30.00 & 57.7 & 45.05 & 65.30 & 100 & 100 & 84.61 & 84.25 & 85.71 & 84.46 \\
\hline $\begin{array}{l}\text { Crangon sp. and } \\
\text { Palaemonetes sp. }\end{array}$ & $\begin{array}{l}\text { Sand and grass } \\
\text { shrimp }\end{array}$ & $5 \quad 1.41$ & 0.47 & & & 1.10 & 0.29 & & & 7.69 & 1.24 & 7.14 & 1.22 \\
\hline \multicolumn{2}{|c|}{ Unidentified fish remains } & 36.62 & 28.93 & 65.00 & 38.99 & 42.86 & 32.85 & & & 23.08 & 14.51 & 21.43 & 14.32 \\
\hline \multicolumn{2}{|c|}{ Unidentified shrimp remains } & 1.41 & 0.43 & & & 1.10 & 0.26 & & & & & & \\
\hline \multicolumn{2}{|l|}{ Total fish } & 100 & 99.1 & 100 & 99.58 & 100 & 99.28 & 100 & 100 & 92.30 & 98.76 & & 98.78 \\
\hline \multicolumn{2}{|l|}{ Eelgrass } & & & & & & & & $00 \quad 0.42$ & 1.10 & 0.16 & & \\
\hline \multicolumn{2}{|c|}{ Total stomachs analyzed } & \multicolumn{2}{|c|}{80} & \multicolumn{2}{|c|}{24} & \multicolumn{2}{|c|}{114} & \multicolumn{2}{|r|}{1} & \multicolumn{2}{|c|}{16} & \multicolumn{2}{|c|}{17} \\
\hline \multicolumn{2}{|c|}{ Number containing prey } & \multicolumn{2}{|c|}{61} & \multicolumn{2}{|c|}{20} & \multicolumn{2}{|c|}{91} & & 1 & \multicolumn{2}{|c|}{13} & \multicolumn{2}{|c|}{14} \\
\hline \multicolumn{2}{|c|}{ Dates bluefish were collected } & \multicolumn{2}{|c|}{$\begin{array}{l}\text { Aug } 25 \\
\text { to Sep } 29\end{array}$} & \multicolumn{2}{|c|}{$\begin{array}{c}\text { Sep } 17 \\
\text { to Sep } 29\end{array}$} & & & \multicolumn{2}{|c|}{ Aug 22} & \multicolumn{2}{|c|}{ Aug 30} & & \\
\hline
\end{tabular}

dia menidia size versus spring-spawned bluefish size had the steepest slope $(0.3540, \mathrm{n}=110)$ when compared to either the shrimp size $(t=7.0730, \mathrm{df}=178, \mathrm{p}<$ $0.05)$ or the bay anchovy size $(t=5.5204$, $d f=194, p<$ $0.05)$ regressions. The slopes $(t=0.7346, \mathrm{df}=151, \mathrm{p}>$
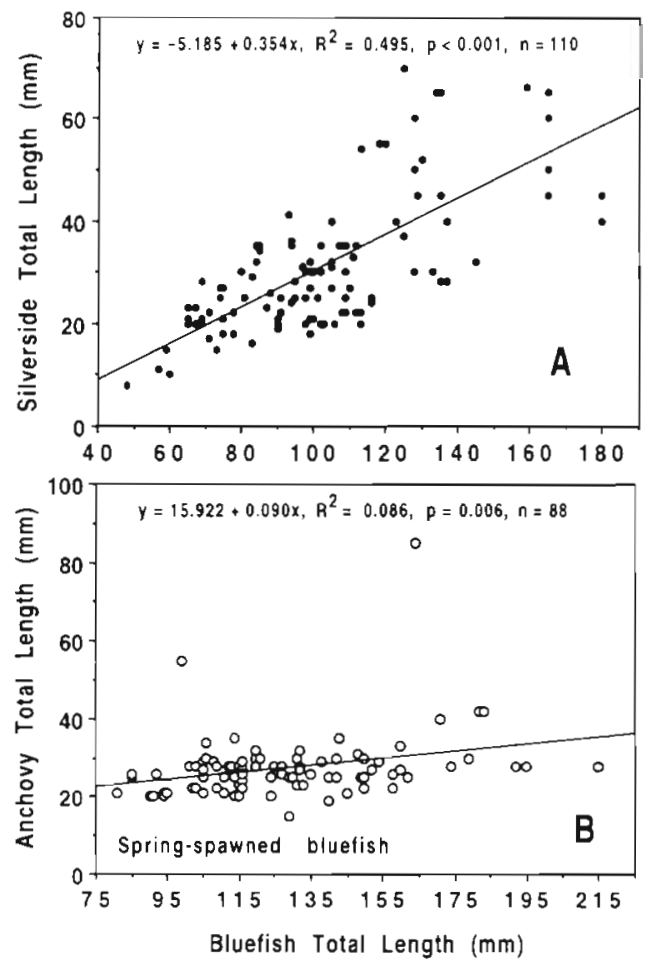

$0.05)$ and elevations $(t=1.9244, \mathrm{df}=152, p>0.05)$ of the bay anchovy and shrimp regressions were statistically indistinguishable.

The comparison of predator-prey relationships between spring- and summer-spawned cohorts could
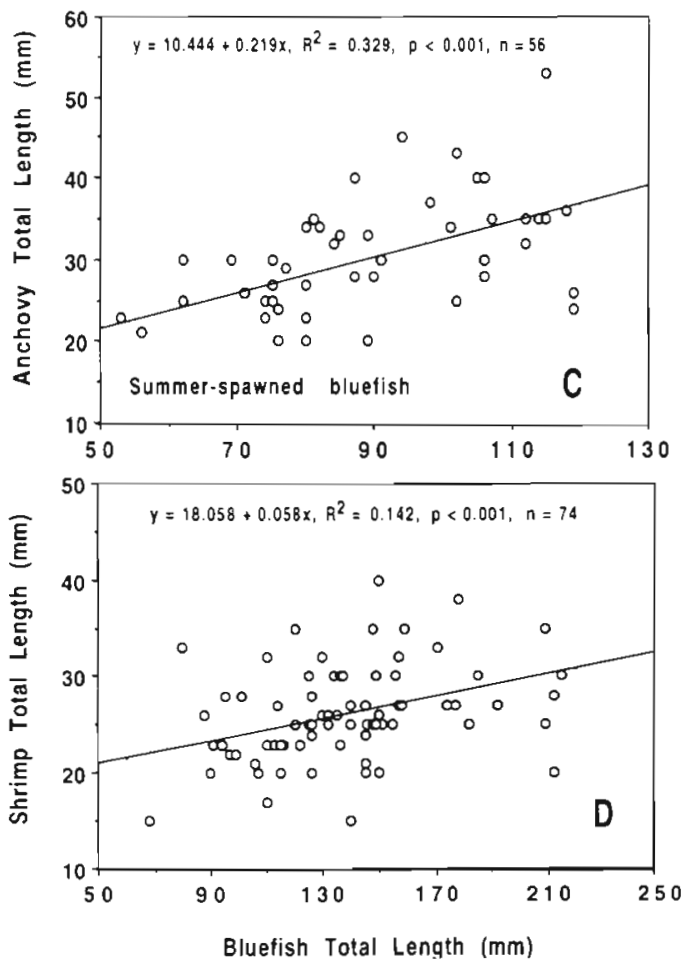

Fig. 6. Relationships between (A) total length of Menidia menidia and spring-spawned bluefish, (B) total length of Anchoa mitchilli and spring-spawned bluefish, (C) total length of $A$. mitchilli and summer-spawned bluefish, (D) total length of shrimps Palaemonetes spp. and Crangon septemspinosa and spring-spawned bluefish 

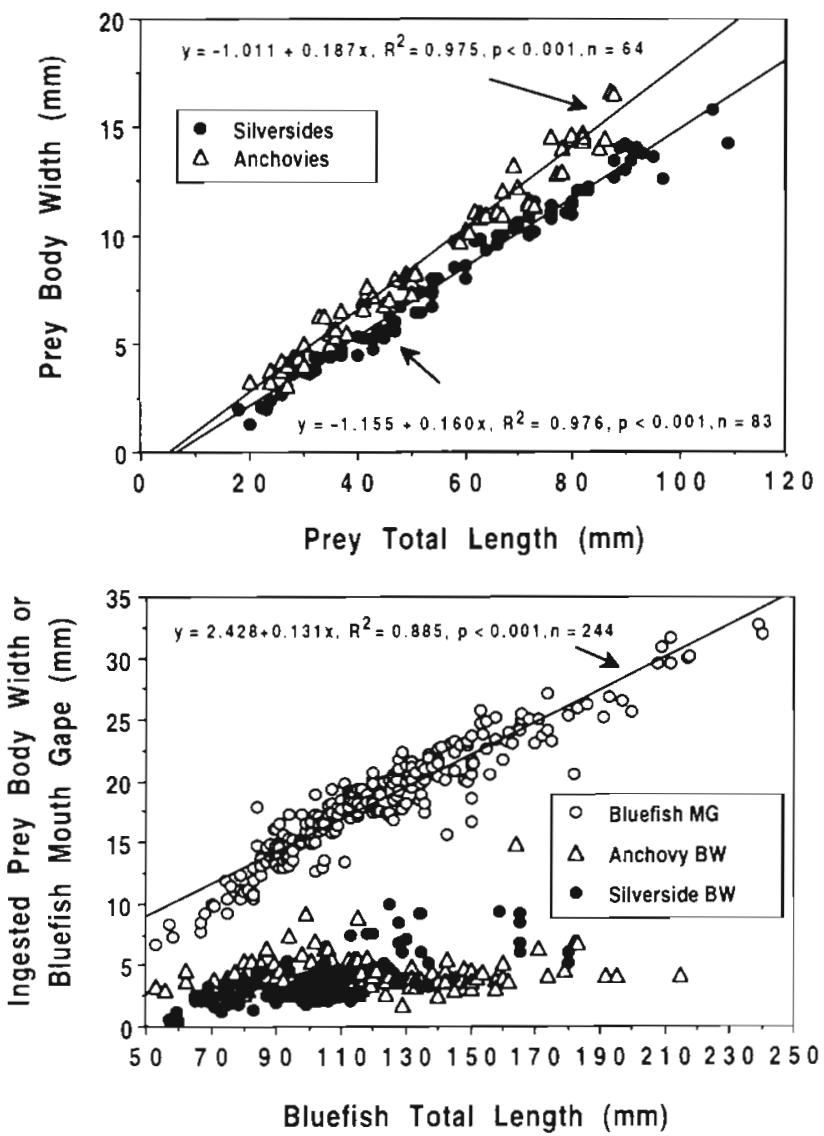

Fig. 7 Top: relationships between body widths and total length for Menidia menidia and Anchoa mitchilli. Bottom: comparison of bluefish mouth gape (MG) versus total length relationship and body widths ( $B W$ ) of ingested bay anchovies and Atlantic silversides. Prey widths were calculated from length-width regressions (see text)

be done only with bay anchovies, the sole common prey for both cohorts (Fig. 6). The slope of the relationship of bay anchovy versus summer-spawned bluefish was greater than that for the spring-spawned fish $(t=$ 2.3422 , df $=135, p<0.05$ ), but was not significantly different from the slope for the regression of Menidia menidia versus spring-spawned bluefish $(t=1.6720$, $\mathrm{df}=157, \mathrm{p}>0.05)$.

\section{Predator mouth gape versus prey body width}

Young-of-the-year bluefish are rarely gape-limited by either of their main prey items, Menidia menidia or Anchoa mitchilli (Fig. 7). Maximum prey lengths are about $100 \mathrm{~mm}$ TL which correspond to a maximum width of 15 to $17 \mathrm{~mm}$. Only the smallest bluefish (<90 $\mathrm{mm}$ TL) would be unable to ingest the largest prey sizes (>80 $\mathrm{mm} \mathrm{TL}$ ). Larger predators ( $>90 \mathrm{~mm} \mathrm{TL}$ ) would not be gape-limited by any size of either $M$. menidia or A. mitchilli prey. However, when comparing the width of Atlantic silverside and bay anchovy prey ingested by bluefish it is clear that all prey are well below the maximum prey size as determined by predator mouth gape (Fig. 7).

\section{Prey size selection}

The high frequency of non-normal prey size distributions in both gut and field samples, as determined by the Shapiro-Wilk test (Zar 1984), required the use of non-parametric methods for their comparison. In general, when the Kolmogorov-Smirnov test resulted in significant differences between frequency distributions, both the Mann-Whitney and the median test detected significant differences in means and medians respectively (Juanes 1992). In all cases where significant differences were found, the median of the prey distribution in the gut was smaller than that of the prey distribution sampled in the field on that date (Fig. 8). The results showed that bluefish consistently ingested smaller-than-average prey. This pattern was strongest for Menidia menidia distributions from spring-spawned fish and for bay anchovies consumed by summer-spawned bluefish (all medians were significantly different; Fig. 8A, C). Two of the 4 comparisons of size distributions for bay anchovies from spring-spawned bluefish (Fig. 8B) and 1 of the 3 shrimp size distribution comparisons (Fig. 8D) had significantly different medians.

\section{DISCUSSION}

Our results demonstrate first that the timing of inshore bluefish migration occurs coincidental with or just after the recruitment of their principal prey. Second, the estuarine diet of spring-and summer-spawned bluefish is determined largely by prey abundance and size at the time of entry into the estuary. Spring-spawned bluefish feed initially on the most abundant spring-spawned prey (Menidia menidia) then later switch to an abundant summer-spawned prey (Anchoa mitchilli). Summerspawned bluefish feed exclusively on summerspawned prey (A. mitchilli). Third, in general it is the smallest members of a given prey assemblage that are consumed. Coupled with prior studies showing similar timing into other estuaries (Juanes et al. 1994), increased growth after inshore migration (McBride \& Conover 1991) and increased growth on a fish diet (Juanes \& Conover 1994a), these findings strongly support our hypothesis concerning the advantages for piscivores of being spawned in advance of their piscine prey. We elaborate below. 
A

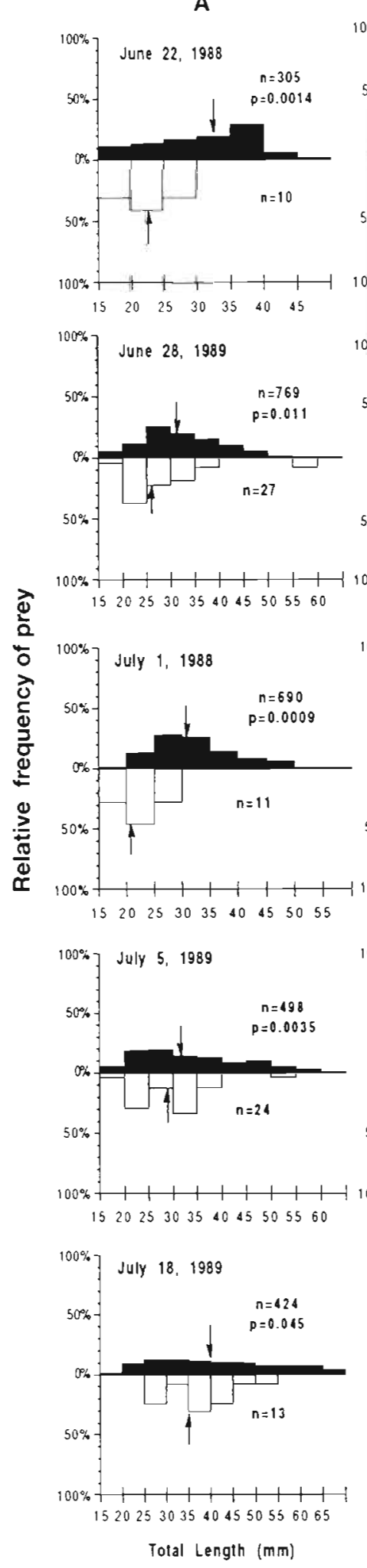

B
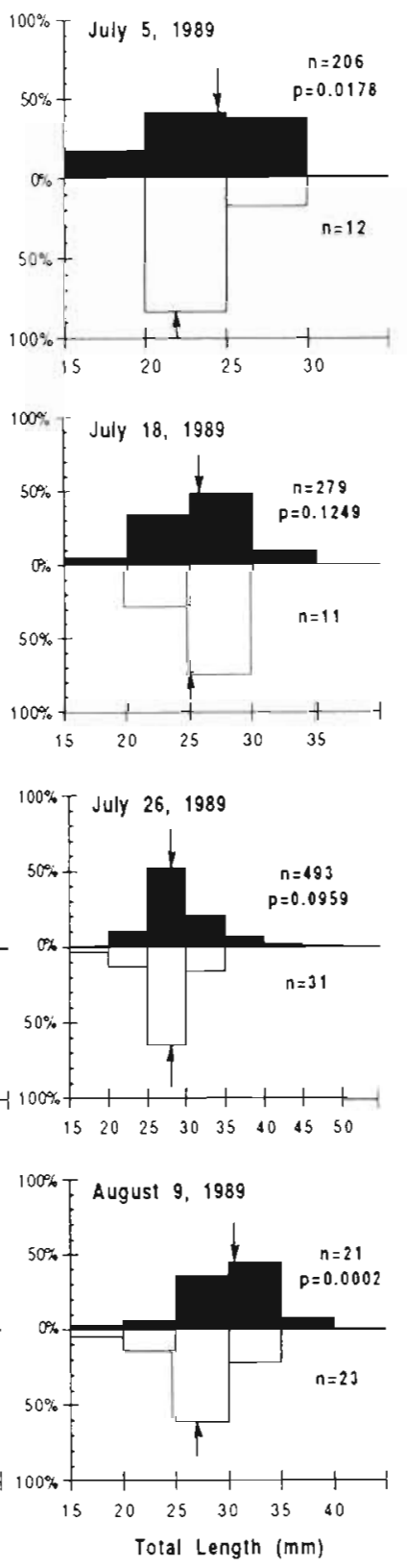

C
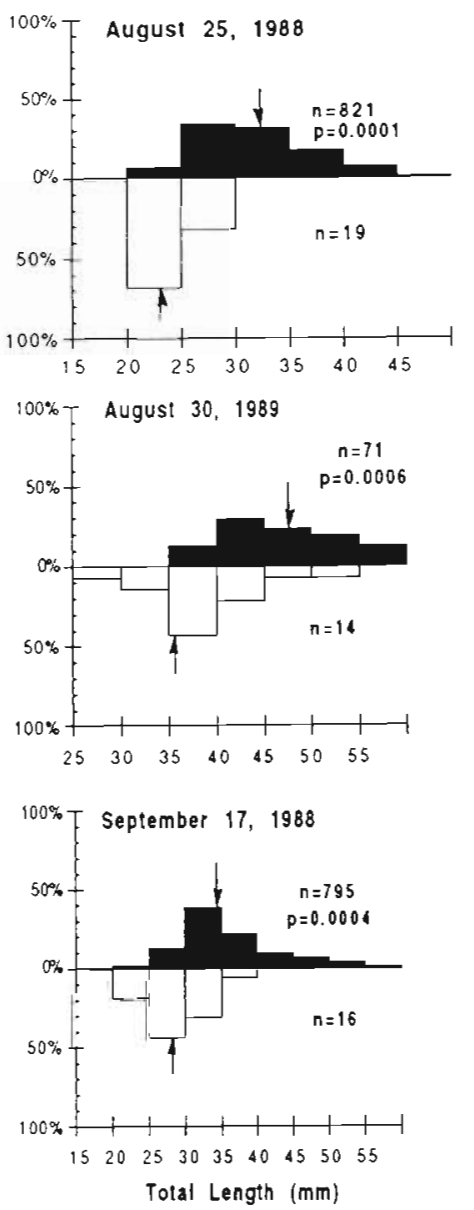

$\square$ FIELD
D
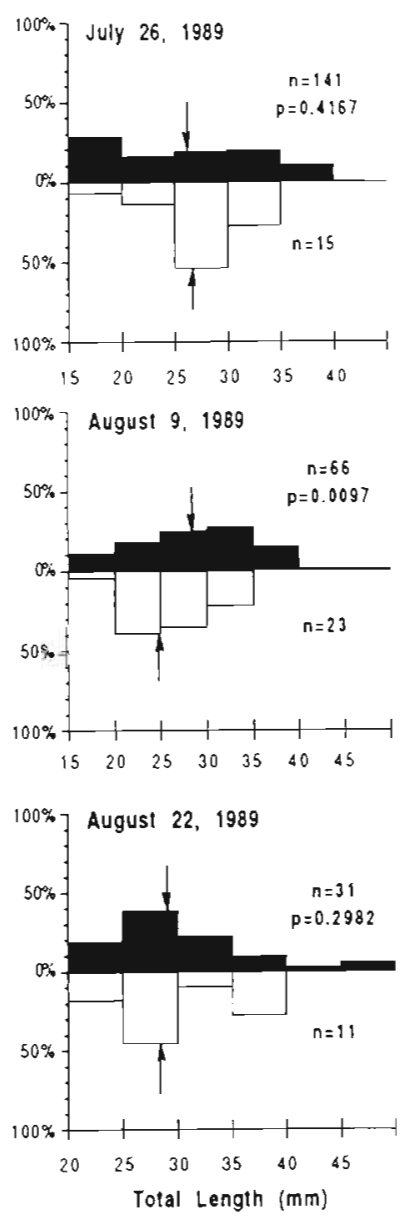

Fig. 8. Comparison between the length frequency distributions of prey found in bluefish guts and the same prey species collected in the field on the same dates. Arrows point to the medians of each distribution. $n$ : number of fish measured, $p$ : probability value of the median test. If $p<0.05$, the 2 medians are significantly different from each other. (A) Atlantic silversides, (B) bay anchovies found in spring-spawned bluefish guts, (C) bay anchovies found in summer-spawned bluefish guts, (D) shrimp Palaemonetes spp. and Crangon septemspinosa

\section{Predator-prey recruitment}

The results suggest a close match between springspawned bluefish and Atlantic silversides, their main prey item during the early stages of their estuarine residency (Fig. 2). Although both fish species tended to appear for the first time on the same sampling date, their peaks in abundance were consistently off- 
set by 1 or 2 sampling periods. Summer-spawned bluefish and their main prey item (bay anchovy) showed a greater variability in relative abundances and the timing of their peaks. This variability could be due to the lowered sampling frequency in late summer in 2 of the 3 years where data are available (1988 and 1989) and the generally high unpredictability of bay anchovy catches, perhaps caused by highly aggregated schools and more pelagic lifestyle of Anchoa mitchilli as compared to Atlantic silversides (Vouglitois et al. 1987, J, Cowan, Dept. Mar. Sci., Univ. S. Alabama, pers. comm.). Interestingly, in 1989 when bay anchovy recruitment occurred relatively early (Figs. 2 \& 4), spring-spawned bluefish abundances appeared to remain at high levels (near peak abundance, as compared to 1988 and 1990 ; Fig. 2). This prolonged peak coincided with a high relative consumption of bay anchovies (as compared to 1988; Fig. 4) and a low abundance of the summerspawned cohort.

Henderson \& Holmes (1989) observed a similar relationship between the abundances of young-of-the-year whiting Merlangius merlangus and their main prey item (the common shrimp Crangon crangon) in British estuaries. They show that predator and prey (both of which are offshore spawners) coincide in the dates of recruitment to the estuary and in subsequent abundance peaks. Similar relationships between the abundance of piscivorous fish and their prey have been hypothesized in a variety of other systems (Walters et al. 1986, Methven \& Piatt 1989, Fogarty et al. 1991).

\section{Diet}

Several previous studies examining feeding of juvenile bluefish along the east coast of North America have shown these diets to be predominantly piscivorous. Main prey items are usually Atlantic silversides and bay anchovies with a small percentage of invertebrates (mostly mysids and shrimp) found in the smaller predators (McDermott 1983, Friedland et al. 1988, Juanes et al, 1993). The results of our study show that Atlantic silversides and bay anchovies were the most abundant items in Great South Bay (Fig. 3) and also dominated YOY bluefish diets in GSB (Fig. 4). However, the predominance of these food items changed with bluefish size and cohort, season, and year. Thus, spring-spawned fish switched from Atlantic silversides to bay anchovies in midsummer when bay anchovies became abundant (particularly in 1989), whereas summer-spawned bluefish fed almost completely on bay anchovies through their relative short stay in local estuaries (in both years). Similar results were obtained by Austin \& Amish (1974) for bluefish collected on the north shore of Long Island: Menidia menidia was the main prey item in July, whereas Anchoa mitchilli dominated the diets of bluefish captured in August and September. Studies in other parts of the world also show that YOY bluefish feed predominantly on atherinids and engraulids (Thomson 1957, 1959, Smale 1986, Haimovici \& Krug 1992).

\section{Predator-size prey-size relationships}

The positive linear relationship between predator and prey size indicates that juvenile bluefish tend to consume larger prey as they grow (Fig. 5). This result is common in fish feeding studies and is generally attributed to ontogenetic increases in predator mouth gape and swimming speed (Ivlev 1961, Webb 1986, Persson 1990). However, mean prey size ingested may increase because the maximum prey size ingested increases while minimum prey sizes remain constant (Wilson 1975, Polis 1988, Cohen et al, 1993). In our study, although mean prey size increased with bluefish size, minimum prey size increased only slightly as compared to the sharp increase in maximum prey size with increasing predator size. Wilson (1975) proposed that such a pattern may apply to most particulate feeders and that it leads to an asymmetry in resource use.

Although YOY bluefish were not gape-limited by most sizes of their main prey items (Fig. 7), they ingested fish prey well below their physical capabilities (as measured by mouth gape vs prey width; Fig. 7) and demonstrated preferential ingestion of the smaller prey sizes in the field (Fig. 8). Laboratory experiments using YOY bluefish as the predator and Atlantic silversides as the prey also showed strong selectivity for small prey sizes when a choice was available (Juanes \& Conover 1994b). Selection of small prey sizes was found in many studies of other piscivores (Juanes 1994). Behavioural experiments performed with YOY bluefish suggested that these apparent preferences were a reflection of size-dependent capture success rates (Juanes \& Conover 1994b). All prey sizes were attacked at similar rates, but smaller prey were most often ingested because they were easier to catch.

\section{Prey size selection and prey life histories}

Although both spring- and summer-spawned bluefish cohorts experience essentially the same community of potential prey species, their diets are very different during their estuarine residency (Figs. 3 \& 4). Spring-spawned bluefish recruit to Great South Bay in early June, soon after Menidia menidia juvenile recruitment (Fig. 2). M. menidia is a spring spawner 
(Conover \& Ross 1982, Conover \& Present 1990), so that by early June in New York, most juvenile recruitment has occurred. As Atlantic silversides grow, the mean size of prey available to bluefish also increases. Bluefish predation tracks Atlantic silverside growth by increasing the average size of prey consumed resulting in a relatively steep relationship between the sizes of predator and prey (Fig. 6A) but consistent selection of smaller-than-average prey (Fig. 8A).

The bay anchovy and both shrimp species are summer spawners (Crangon septemspinosa, Haefner 1979; Palaemonetes vulgaris, Yan 1987; Anchoa mitchilli, Zastrow et al. 1991), resulting in consistent juvenile recruitment and potential availability of small prey sizes throughout the summer in GSB. The availability of these selected sizes of prey leads to their disproportionate ingestion by spring-spawned YOY bluefish. Consistent ingestion of these small prey results in shallower slopes in the predator-prey regressions (Fig. 6B, D) than those for Atlantic silverside prey (Fig. 6A).

Summer-spawned bluefish recruit to GSB in late summer (Fig. 2), after the bay anchovy reproductive peak (Castro \& Cowen 1991), and prey almost exclusively on bay anchovy. Prey sizes consumed by the summer-spawned bluefish cohort track the growth of its principal prey resulting in a higher slope than that for the spring-spawned bluefish-bay anchovy regression (Fig. 6C). Like the spring-spawned cohort, summer-spawned fish show strong selection for prey smaller than the mean size available (Fig. 8C) and negligible increases in minimum prey sizes ingested.

Similar seasonal diet shifts were observed for YOY walleye Stizostedion vitreum and age 2 yellow perch Perca flavescens in Lake Erie (Knight et al. 1984). Walleyes ate age 1 shiners Notropis atherinoides and $N$. hudsonius in spring but switched to YOY clupeids Dorosoma cepedianum and Alosa pseudoharengus in summer and ingested YOY shiners and clupeids in autumn as each of these prey became abundant. Yellow perch ate invertebrates in spring and early summer, and clupeids and shiners in late summer and autumn. These feeding shifts were determined partially by changes in the relative abundance of prey species, prey species selection (i.e. certain abundant fish were rarely consumed), but mostly by prey size availability. Thus all sizes of predators preferred small prey, although older predators ( $>220 \mathrm{~mm}$ TL) ate prey from a wider length range (20 to $130 \mathrm{~mm} \mathrm{TL}$ ) than smaller predators ( 60 to $220 \mathrm{~mm}$ ) which were restricted to small prey sizes ( 20 to $80 \mathrm{~mm}$ ).

The diet comparisons presented here illustrate the size-structured nature of bluefish feeding ecology. Predation tends to be sized-based rather than speciesbased, resulting in different diets but similar predator- size prey-size relationships. Our results suggest that the outcome of these size-structured interactions can be examined by considering predator selectivities, as well as timing of recruitment and growth of both predators and prey. The size-structured interaction between piscivorous fish predators and their prey was recently simulated using individual-based modeling approaches (Adams \& DeAngelis 1987, Crowder et al. 1992, Rice et al. 1993a, b). These models and associated experimental tests suggest that variations in relative growth rate of predators and prey, predator size preferences and the timing of the shift to piscivory were among the most important variables affecting the outcome of interactions between predator and prey populations. The field-based results of this study confirm the modeling and experimental results and suggest that size-structured interactions may be an important force in the selection of predator life histories, and in particular the evolution of the onset of piscivory.

\section{Accelerating the onset of piscivory}

As fish grow they commonly undergo a series of ontogenetic shifts in diet and habitat which are usually associated with changes in either growth or mortality rates (Werner \& Gilliam 1984, Persson 1990, Persson \& Diehl 1990). Ontogenetic shifts in diet from invertebrate to fish prey, for example, are associated with a concommitant increase in growth rate and/or condition in several fishes (Larkin et al. 1957, Martin 1966, Paloheimo \& Dickie 1966, Wicker \& Johnson 1987). After recruitment to the shore zone, YOY bluefish double their growth rate (from $0.75-1.0 \mathrm{~mm} \mathrm{~d}^{-1}$ to $1.3-1.7 \mathrm{~mm} \mathrm{~d}^{-1}$, McBride \& Conover 1991). The increase in growth is mainly due to the diet shift from planktivory to piscivory (Juanes \& Conover 1994a) which is coincident with the habitat shift to inshore waters (Marks \& Conover 1993). The large body size attained by bluefish at the end of the first growing season $(-250 \mathrm{~mm})$ may substantially increase foraging efficiency (Juanes \& Conover 1994b) and survival during the ensuing southward migration and winter.

The tendency for specialized piscivorous fishes to spawn early enough to get a size advantage on their prey has been documented for various freshwater predator/prey combinations (Frost 1954, Forney 1971 , 1976, Keast 1985a). The interactions between spawning times of predators and prey, timing of feeding shifts, and the relative size and prey type distributions that result may often be critical to determining future year-class strength (Wicker \& Johnson 1987, Buijse \& Houthuijzen 1992). In largemouth bass Micropterus salmoides, for example, overwinter mortality (hence, recruitment) is dependent on size at the end of the first 
growing season: individuals that reach a size large enough to shift their diet to fish grow faster (Aggus \& Elliott 1975, Keast \& Eadie 1985, Bettoli et al. 1992), attain a larger size by fall (Chodorowski 1975, Shelton et al. 1979), and thereby have a higher probability of surviving the winter (Gutreuter \& Anderson 1985).

Bluefish accelerate the onset of piscivory by being spawned earlier and at a lower latitude and being advected by physical forces into northern estuaries (Juanes et al. 1994). Advection thus permits springspawned bluefish to expand the habitats they can colonize by exploiting high latitude environments at an earlier time and at a larger size than would be possible for a fish spawned in the mid-Atlantic Bight.

The advantage of earlier birthdates and the shift to a piscivorous diet is evident from comparison of size at age 1 and dominant prey type in several middle Atlantic Bight fish (Table 1). The only species that reach lengths greater than $200 \mathrm{~mm}$ by age 1 are bluefish and summer flounder Paralichthys dentatus L.; and these are also the only 2 species whose diet over the first summer of life is primarily fish. It is of interest to note that summer flounder are also unique in regard to spawning time. Unlike most other species listed in Table 1, summer flounder are spawned in autumn and overwinter as larvae. Metamorphosing summer flounder larvae enter New Jersey estuaries in early winter through the following spring and therefore begin their first growing season at an advanced age and size (Szedlmayer et al. 1992). Hence, their large size at age 1 (which actually is size at second winter) is a function of both earlier birthdate (autumn of the prior year) and the ontogenetic shift to piscivory, but for a different reason than in bluefish.

The only other marine species known to have a similar relationship between spawning, advection, inshore recruitment, and a shift to piscivory leading to rapid growth are 2 ommastrephid squids (Illex illecebrosus, O'Dor 1983, Trites 1983, Dawe 1988; Todarodes pacificus, Okutani 1983, Jefferts 1986, Mann \& Lazier 1991)

\section{Bluefish spawning seasons - adaptive or not?}

Our results suggest that the timing and location of spawning in Atlantic coast bluefish is adaptive. Spawning in the SAB in spring occurs near the edge of the northward-flowing Gulf Stream (Kendall \& Walford 1979), providing both transport to and a head-start on the growing season in northern estuaries (McBride \& Conover 1991, McBride et al. 1993). In contrast, summer-spawning occurs over the middle of the shelf, far from the Gulf Stream's influence. This increases the probability that summer progeny will be retained in the $M A B$, rather than being carried eastward into the
Atlantic Ocean. Summer-spawned YOY also shift to piscivory upon inshore migration, but the size they attain by the end of the growing season is much less than that for spring-spawned fish. Coincidentally, it is the spring-spawned cohort that predominates in both YOY surveys (McBride \& Conover 1991, McBride et al. 1993) and among the adult stock (Chiarella \& Conover 1990).

In contrast, Hare \& Cowen (1993) speculated that the spawning patterns of bluefish along the US east coast are maladaptive. They argued that the spawning seasons of bluefish along the coast actually represent 1 continuous event and that the bimodal juvenile recruitment patterns reflect effects of circulation on relative transport success of offspring to the $M A B$. Although our conclusions are not dependent on the existence of 2 'distinct' spawning seasons, we disagree with Hare \& Cowen's interpretation. The limited gonadosomatic index data available along the Atlantic coast show 2 peaks: 1 in March and April off the southeast Florida coast (Figs. $3 \& 4$ in Hare \& Cowen 1993) and 1 in the MAB in July IChiarella \& Conover (1990), note that Hare \& Cowen (1993) pooled the gonadosomatic index data for the MAB in a manner that reduced the magnitude of the peak]. We agree that data pooled across numerous cruises, months, years, sampling programs and regions of the coast do not indicate a clear bimodal pattern of larval abundance. But this may well reflect nothing more than the homogenizing effect of pooling across extremely spotty and disparate data sets. Moreover, Hare \& Cowen's transport model hinges entirely on an assumption for which no empirical support exists: i.e. the assumption that juveniles not on the shelf at the end of a given transport period perish. This assumption is questionable given their assertion that swimming must be considered part of the transport process. Because spawning in the MAB progresses gradually from south to north, Smith et al. (1994) also concluded that bluefish spawning seasons are continuous, but this evidence does not rule out the possibility of 2 overlapping peaks in spawning. Synoptic data on gonadosomatic index and egg abundances throughout the year and along the entire US east coast are needed to resolve whether bimodal juvenile recruitment patterns are caused by factors other than variation in reproductive output.

Further support for the adaptive hypothesis comes from comparisons of bluefish populations in other regions. Bluefish are distributed circumglobally in all aceans except the Pacific (LeGall 1934, Briggs 1960, van der Elst 1976, Champagnat 1983). In eastern South Africa, bluefish spawn in spring (September to November) off the coast of Durban, the larvae are advected southwards along the Agulhas current and the main juvenile recruitment occurs in various estuaries in the Cape province from December to February (van der 
Elst 1976, Smale \& Kok 1983, Marais 1984, Bennett 1989a, b. Plumstead et al. 1989a, b, Romer 1990). Length at recruitment is 40 to $70 \mathrm{~mm}$ TL (van der Elst 1976, Bennett 1989c), diets are predominantly piscivorous (Smale \& Kok 1983, Marais 1984, Smale 1984. Bennett 1989a), and growth is rapid, reaching a mean size of $250 \mathrm{~mm}$ FL at age 1 (van der Elst 1976).

Similar patterns of spawning, advection and ontogenetic shifts to piscivory are also evident in bluefish populations from: eastern Australia (Bade 1977, Pollock 1984, Halliday 1990); western Australia (Lenanton 1977. Fisheries Department of Western Australia 1990); the Bulgarian coast of the Black Sea (Borcea 1932, Oven 1957, Turgan 1959, Ivanov \& Beverton 1985); and northwest Africa near Mauritania and Senegal (Champagnat 1983).

Such commonality suggests that the observed pattern of spawning, advection, and recruitment may represent a life history strategy that maximizes growth and survival.

Acknowledgements. We thank the many people who helped with field collections and laboratory processing: J. Belmonte, R. Chant, L. Clough, A. Etisham, l. Lagomarsino, R. Marks, R. McBride, J. Schreer, K. Sosebee, R. Tegge, P. Vacheron, and D. van Voorhees. S. Courtenay, J. Estes and 4 anonymous reviewers kindly commented on earlier versions of the manuscript. Discussions with J. Buckel, R. Cowen, J Hare, R. Marks and R. McBride improved our thinking concerning bluefish early life history. Thanks to J. Buckel for help with data in Table 1 This work was funded by a graduate fellowship in population biology from the Electric Power Research Institute (to F.J.), by a research grant from the Hudson River Foundation for Science and Environmental Research Inc. (to D.C.), a postdoctoral fellowship from the Canadian NCE Ocean Production Enhancernent Network (OPEN) (to F.J.), and by the Office of Sea Grant, National Oceanic and Atmospheric Administration (NOAA), under grant NA86AA-DSG045 to the New York Sea Grant Institute (to D.C.). The U.S. Government is authorized to produce and distribute reprints for governmental purposes notwithstanding any copyright notation that may appear hereon. The views expressed herein are those of the authors and do not necessarily reflect the views of NOAA or any of its subagencies. This is contribution number 1000 of the Marine Sciences Research Center, State University of New York, Stony Brook.

\section{LITERATURE CITED}

Adams SM, DeAngelis DL (1987) Indirect effects of early bass-shad interactions on predator population structure and food web dynamics. In: Kerfoot WC, Sih A (eds) Predation: direct and indirect impacts on aquatic communities. University Press of New England, Hanover, $p$ $103-117$

Aggus LR, Elliott GV (1975) Effects of cover and food on yearclass strength of largemouth bass. In: Stroud RH, Clepper $\mathrm{H}$ (eds) Black bass biology and management. Sport Fishing Institute, Washington, p 317-322

Austin H. Amish R (1974) Preoperational ecological monitoring program of the marine environs at the Long Island
Lighting Company, Shoreham Nuclear Power Station, Shoreham, Long Island, NY New York Ocean Science Laboratory, Montauk

Bade TM (1977) The biology of tailor (Pomatomus saltatrix) from the east coast of Australia. MSc thesis, University of Queensland

Bennett BA (1989a) The diets of fish in three south-western Cape estuarine systems. S Afr J Zool 24:163-177

Bennett BA (1989b) The fish community of a moderately exposed beach on the southwestern Cape coast of South Africa and an assessment of this habitat as a nursery for juvenile fish. Estuar coast Shelf Sci 28:293-305

Bennett BA (1989c) A comparison of the fish communities in nearby permanently open, seasonally open and normally closed estuaries in the southwestern Cape, South Africa. $S$ Afr J mar Sci 8:43-55

Bettoli PW, Maceina MJ, Noble RL, Betsill RK (1992) Piscivory in largemouth bass as a function of aquatic vegetation abundance. N Am J Fish Manage 12:509-516

Borcea I (1932) Nouvelles observations sur les migrations et sur le periode de ponte des especes de poissons migrateurs de la mer Noire. Ann Sci Univ Jassy 17:503-564

Briggs JC (1960) Fishes of worldwide (circumtropical) distribution. Copeia 1960:171-180

Buijse AD, Houthuijzen RP (1992) Piscivory, growth, and sizeselective mortality of age 0 pikeperch (Stizostedion lucioperca). Can J Fish aquat Sci 49:894-902

Castro LR, Cowen RK (1991) Environmental factors affecting the early life history of bay anchovy Anchoa mitchilli in Great South Bay, New York. Mar Ecol Prog Ser 76: $235-247$

Champagnat C (1983) Pèche, biologie et dynamique du tassergal (Pomatomus saltatrix, Linnaeus, 1766) sur les côtes Sénégalo-Mauritaniennes. ORSTOM, Paris

Chao LN, Musick JA (1977) Life history, feedıng habits, and functional morphology of juvenile sciaenid fishes in the York River estuary, Virginia. Fish Bull US 75:657-702

Checkley DM, Raman S, Maillet GL, Mason KM (1988) Wınter storm effects on the spawning and larval drift of a pelagic fish. Nature 335:346-348

Chiarella LA, Conover DO (1990) Spawning season and firstyear growth of adult bluefish from the New York Bight Trans Am Fish Soc 119:455-462

Chodorowski A (1975) Formation de populations bimodales chez les alevins de poissons carnassiers. Verh int Verein theor angew Limnol 19:2546-2555

Cohen JE, Pimm SL, Yodzis P, Saldaña J (1993) Body sizes of animal predators and animal prey in food webs. J Anim Ecol 62:67-78

Collins MR, Stender BW (1987) Larval king mackerel (Scomberomorus cavalla), Spanish mackerel (S. maculatus), and bluefish (Pomatomus saltatrix) off the southeast coast of the United States, 1973-1980. Bull mar Sci 41 $822-834$

Conover DO, Present TMC (1990) Countergradient variation in growth rate: compensation for length of the growing season among Atlantic silversides from different latitudes. Oecologia 83:316-324

Conover D O, Ross M R (1982) Patterns in seasonal abundance, growth, and biomass of the Atlantic silverside, Menidia menidia in a New England estuary. Fish Bull US 5:275-286

Crowder LW, Rice JA, Miller TJ, Marschall EA (1992) Empirical and theoretical approaches to size-based interactions and recruitment variability in fishes. In: DeAngelis DL. Gross LJ (eds) Individual-based models and approaches in ecology. Chapman \& Hall, New York, p 237-255

Dawe EG (1988) Length-weight relationships for short-finned 
squid in Newfoundland and the effect of diet on condition and growth. Trans Am Fish Soc 117:591-599

de Lafontaine Y. Lambert $T$, Lilly GR, McKone WD, Miller RJ (eds) (1992) Juvenile stages: the missing link in fisheries research. Can Tech Rep Fish Aquat Sci 1890

Dery L, Livingstone R (1982) Windowpane, Scopthalmus aquosus. In: Grosslein MD, Azarovitz TR (eds) MESA New York Bight atlas monograph 15. New York Sea Grant Institute, Albany, p 114-116

DuPaul WD, McEachran JD (1969) Age and growth of butterfish, Peprilus triacanthus, in the lower York River. Chesapeake Sci 14:205-207

Ebenman B, Persson L (1988) Size-structured populations. Springer-Verlag, New York

Finkelstein SL (1969) Age and growth of scup in Long Island waters. NY Fish Game J 16:84-110

Fisheries Department of Western Australia (1990) Fishing WA-Tailor. Perth

Fogarty MJ, Cohen EB, Michaels WL, Morse WW (1991) Predation and the regulation of sand lance populations: an exploratory analysis. ICES Mar Sci Symp 193:120-124

Forney JL (1971) Development of dominant year-classes in a yellow perch population. Trans Am Fish Soc 100:739-749

Forney JL (1976) Year-class formation in the walleye (Stizostedion vitreum) population of Oneida, New York, 1966-1973. J Fish Res Bd Can 33:783-792

Friedland KD, Garman GC, Bejda AJ, Studholme AL, Olla B (1988) Interannual variation in diet and condition in juvenile bluefish during estuarine residency. Trans Am Fish Soc 117:474-479

Frost WE (1.954) The food of plke, Esox lucius L. in Windermere. J Anim Ecol 23:340-360

Gutreuter SJ, Anderson RO (1985) Importance of body size to the recruitment process in largemouth bass populations. Trans Am Fish Soc 114:317-327

Haefner PA (1979) Comparative review of the biology of north Atlantic caridean shrimps (Crangon), with emphasis on $C$. septemspinosa. Bull biol Soc Wash 3:1-40

Haimovici M. Krug LC (1992) Feeding and reproduction of the enchova Pomatomus saltatrix in southern Brazil. Rev Brasil Biol 52:503-513

Halliday I (1990) Tailor tagging project. Summary of 1988 and 1989 results. Queensland Department of Primary Industries, Brisbane

Hambright KD (1991) Experimental analysis of prey selection by largemouth bass: role of predator mouth width and prey body depth. Trans Am Fish Soc 120:500-508

Hare JA, Cowen RK (1993) Ecological and evolutionary implications of the larval transport and reproductive strategy of bluefish Pomatomus saltatrix. Mar Ecol Prog Ser 98:1-16

Henderson PA, Holmes RHA (1989) Whiting migration in the Bristol Channel: a predator-prey relationship. J Fish Biol 34:409-416

Horn MH (1970) Systematics and biology of the stromateoid fishes of the genus Peprilus. Bull Mus comp Zool 140: $165-262$

Hostetter EB, Munroe TA (1993) Age, growth, and reproduction of tautog Tautoga ontis from coastal waters of Virginia. Fish Bull US 91:45-64

Hovenkamp F (1991) Immigration of larval plaice (Pleuronectes platessa L.) into the western Wadden Sea: a ques. tion of timing. Neth J Sea Res 27:287-296

Hyslop EJ (1980) Stomach contents analysis - a review of methods and their application. J Fish Biol 17:411-429

Ivanov L, Beverton RJH (1985) The fishenes resources of the Mediterranean. Part 2. Black Sea. Stud Rev gen Fish Coun Mediterr FAO 60:1-135
Ivlev VS (1961) Experimental ecology of the feeding of fishes Yale University Press, New Haven

Jefferts K (1986) Cephalopod fisheries of the north Pacific and their management. In: Jamieson GS, Bourne $\mathrm{N}$ (eds) North Pacific Workshop on stock assessment and management of invertebrates. Can Spec Publ Fish Aquat Sci 92:34-56

Jennings S, Pawson MG (1992) The origin and recruitment of bass, Dicentrarchus labrax, larvae to nursery areas. J mar biol Ass UK 72:199-212

Juanes $F$ (1992) The advantages of advection: recruitment, piscivory, growth, and consumption of young-of-the-year bluefish (Pomatomus saltatrix). PhD dissertation, State University of New York, Stony Brook

Juanes F (1994) What determines prey size selectivity in piscivorous fishes? In: Stouder DJ, Fresh KL, Feller RJ (eds) Theory and application in fish feeding ecology. Belle W Baruch Library in Marine Sciences. No. 18, S Carolina Univ Press, Columbia, p 79-100

Juanes F, Buckel JA, Conover DO (1994) Accelerating the onset of piscivory: intersection of predator and prey phenologies. J Fish Biol 45 (Suppl A):41-54

Juanes F, Conover DO (1994a) Rapid growth, high feeding rates, and early piscivory in young-of-the-year bluefish (Pomatomus saltatrix). Can J Fish aquat Sci 51:1752-1761

Juanes F, Conover DO (1994b) Piscivory and prey size selection in young-of-the-year bluefish: predator preference or size-dependent capture success? Mar Ecol Prog Ser 114 $59-69$

Juanes F, Marks RE, McKown KA, Conover DO (1993) Predation by age- 0 bluefish on age- 0 anadromous fishes in the Hudson River estuary. Trans Am Fish Soc 122:348-356

Keast A (1985a) The piscivore guild of fishes in small Freshwater ecosystems. Environ Biol Fish 12:119-129

Keast A (1985b) Development of dietary specializations in a summer community of juvenile fishes. Environ Biol Fish 13:211-224

Keast A, Eadie J (1985) Growth depensation in year-0 largemouth bass: the influence of diet. Trans Am Fish Soc 114: $204-213$

Kendall AW, Walford LA (1979) Sources and distribution of bluefish. Pomatomus saltatrix, larvae and juveniles off the east coast of the United States. Fish Bull US 77:213-227

Kerfoot WC, Sih A (1987) Predation: direct and indirect impacts on aquatic communities. University Press of New England, Hanover, $\mathrm{NH}$

Knight RL, Margraf FJ, Carline RF (1984) Piscivory by walleyes and yellow perch in western Lake Erie. Trans Am Fish Soc 113:677-693

Larkin PA, Terpenning JG, Parker RR (1957) Size as a determinant of growth rate in rainbow trout Salmo gairdneri. Trans Am Fish Soc 86:84-96

LeGall J (1934) Le tassergal ou bluefish (Pomatomus saltatrix Lacepede = Temnodon saltator Linnel. Résumé des connaissances acquises sur la biologie et l'utilisation de ce poisson. Rev Trav Inst Pêches marit 7:27-85

Lenanton RCJ (1977) Aspects of the ecology of fish and commercial crustaceans of the Blackwood River estuary, Western Australia. Fish Res Bull West Aust 19:1-72

Lenanton RCJ. Potter IC (1987) Contribution of estuaries to commercial fisheries in temperate western Australia and the concept of estuarine dependence. Estuaries 10:28-35

Liem AH (1924) The life history of the shad (Alosa sapidissima Wilson) with special reference to the factors limiting its abundance. Contr Can Biol Fish 2:163-284

Mann KH, Lazier JRN (1991) Dynamics of marine ecosystems. Biological-physical interactions in the oceans. Blackwell 
Scientific Publications, Boston

Marais JFK (1984) Feeding ecology of major carnivorous fish from four eastern Cape estuaries. S Afr J Zool 19:210-223

Markle DF, Grant GC (1970) The summer food habits of young of-the-year striped bass in three Virginia rivers. Chesapeake Sci 11:50-54

Marks RE. Conover DO (1993) Ontogenetic shift in the diet of young-of-year bluefish Pomatomus saltatrix during the oceanic phase of the early life history. Fish Bull US 91. 97-106

Martin MV (1966) The significance of food habits in the biology, exploitation, and management of Algonquin Park, Ontario, lake trout. Trans Am Fish Soc 95:415-422

McBride RS (1989) Comparitive growth and abundance of spring-versus summer-spawned young-of-the-year bluefish, Pomatomus saltatrix, recruiting to the New York Bight. MSc thesis, State University of New York, Stony Brook

McBride RS, Conover DO (1991) Recruitment of young-ofthe-year bluefish Pomatomus saltatrix to the New York Bight: variation in abundance and growth of spring- and summer-spawned cohorts. Mar Ecol Prog Ser 78:205-216

McBride RS, Ross JL, Conover DO (1993) Recruitment of bluefish Pomatomus saltatrix to estuaries of the US South Atlantic Bight. Fish Bull US 91:389-395

McDermott JJ (1983) Food web in the surf zone of an exposed sandy beach along the mid-Atlantic coast of the United States. In: McLachlan A, Erasmus T (eds) Sandy beaches as ecosystems. W Junk, The Hague, p 529-537

Methven DA, Piatt JF (1989) Seasonal and annual variation in the diet of Atlantic cod (Gadus morhua) in relation to the abundance of capelin (Mallotus villosus) off eastern Newfoundland, Canada. J Cons int Explor Mer 45: 223-225

Nyman RN, Conover DO (1988) The relation between spawning season and recruitment of young-of-the-year bluefish, Pomatomus saltatrix, to New York. Fish Bull US 86:237-250

O'Dor RK (1983) Illex illecebrosus. In: Boyle PR (eds) Cephalopod life cycles, Vol 1. Academic Press, London, p 175-199

Okutani T (1983) Todarodes pacificus. In: Boyle PR (eds) Cephalopod life cycles. Vol 1. Academic Press, London, p $201-214$

Oven LS (1957) On the drifting approach of fingerling bluefish (Pomatomus saltatrix) (Linnaeus) to the shores of the Black Sea in the Karadaga region (1947-1954). Tr Karadag Biol Stn, Akad Nauk Ukr 14:155-157

Pacheco AL (1962) Age and growth of spot in lower Chesapeake Bay, with notes on distribution and abundance of juveniles in the York River system. Chesapeake Sci 3:18-28

Paloheimo JE, Dickie LM (1966) Food and growth of fishes. III. Relations among food, body size, and growth efficiency. J Fish Res Bd Can 23:1209-1240

Persson L (1990) Predicting ontogenetic niche shifts in the field: What can be gained by foraging theory? In: Hughes RN (eds) Behavioural mechanisms of food selection. NATO ASI, C20 Sprnger-Verlag, Berlin, p 303-321

Persson L, Diehl S (1990) Mechanistic individual-based approaches in the population/community ecology of fish. Annls Zool fenn 27:165-182

Plumstead EE, Prinsloo JF, Schoonbee HJ (1989a) A survey of the fish fauna of Transkei estuaries. Part two: the Mbashe estuary. S Afr J Zool 24:273-281

Plumstead EE, Prinsloo JF, Schoonbee HJ (1989b) A survey of the fish fauna of Transkei estuaries. Part three: the Mtata River estuary. S A.fr J Zool 24:282-289

Polis G (1988) Exploitation competition and the evolution of interference, cannibalism, and intraguild predation in age/size structured populations. In: Ebenman B, Persson L (eds) Size-structured populations. Springer-Verlag, New York, p 185-202

Pollock BR (1984) The tailor (Pomatomus saltatrix) fishery at Fraser Island and its relation to the life-history of the fish. Proc R Soc Queens1 95:23-28

Poole JC (1961) Age and growth of fluke in Great South Bay and their significance to the sport fishery. NY Fish Game J $8: 1-18$

Popova OA (1978) The role of predaceous fish in ecosystems. In: Gerking SD (eds) Ecology of freshwater fish production. John Wiley \& Sons, New York, p 215-249

Raney RC, Tresselt EF, Hollis EH, Vladykov VD, Wallace DH (1952) The life history of the striped bass, Roccus saxatilis (Walbaum). Bull Bingham Oceanogr Coll 14:5-97

Reimchen TE (1990) Size-structured mortality in a threespine stickleback (Gasterosteus aculeatus)-cutthroat trout (Oncorhynchus clarki) community. Can J Fish aquat Sci 47 : $1194-1205$

Rice JA, Crowder LB, Rose KA (1993a) Interactions between size-structured predator and prey populations: experimental test and model comparison. Trans Am Fish Soc 122:481-491

Rice JA, Miller TJ, Rose KA, Crowder LB, Marschall EA, Trebitz AS, DeAngelis DL (1993b) Growth rate variation and larval survival: inferences from an individual-bāsed size-dependent predation model. Can J Fish aquat Sci 50: $133-142$

Richards SW, Mann JM, Walker JA (1979) Comparison of spawning seasons, age, growth rates, and food of two sympatric species of searobins, Prionotus carolinus and Prionotus evolans, from Long lsland Sound. Estuaries 2: $255-268$

Romer GS (1990) Surf zone fish community and species response to a wave energy gradient. J Fish Biol 36:279-287

Ross MR (1991) Recreational fisheries of coastal New England. University of Massachusetts Press, Amherst

Rountree RA, Able KW (1992) Foraging habits, growth, and temporal patterns of salt-marsh creek habitat use by young-of-the-year summer flounder in New Jersey. Trans Am Fish Soc 121:765-776

Schaefer RH (1960) Growth and feeding habits of the whiting or silver hake in the New York Bight. NY Fish Game J 7 85-98

Scott WB, Scott MG (1988) Atlantic fishes of Canada. Can Bull Fish aquat Sci 219

Shelton WL, Davies WD, King TA, Timmons TJ (1979) Variations in the growth of the initial year class of largemouth bass in West Point Reservoir, Alabama and Georgia. Trans Am Fish Soc 108:142-149

Shima M (1990) Oceanic transport of the early life history stages of bluefish, Pornatomus saltatrix, from Cape Hatteras to the mid-Atlantic Bight. MSc thesis, State University of New York, Stony Brook

Smale MJ (1984) Inshore small-mesh trawling survey of the Cape south coast. Part 3 . The occurrence and feeding of Argyrosomus hololepidotus, Pomatomus saltatrix and Merluccius capensis. S Afr J Zool 19:170-179

Smale MJ (1986) The feeding habits of six pelagic and predatory teleosts in eastern Cape coastal waters (South Africa). J Zool Ser B 1 (Part 2):357-410

Smale MJ, Kok HM (1983) The occurrence and feeding of Pomatomus saltatrix (elf) and Lichia amia (leervis) in two Cape south estuaries. S Afr J Zool 18:337-342

Smith W, Berrien P, Potthoff T (1994) Spawning patterns of bluefish, Pomatomus saltatrix, in the Northeast continental shelf ecosystem. Bull mar Sci 54:8-16

Stergiou KI, Fourtouni H (1991) Food habits, ontogenetic diet 
shift and selectivity in Zeus faber Linnaeus, 1758. J Fish Biol 39:589-603

Szedlmayer ST, Able KW, Rountree RA (1992) Growth and temperature-induced mortality of young-of-the-year summer flounder (Paralichthys dentatus) in southern New Jersey. Copeia 1992:120-128

Thomson JM (1957) The food of Western Australian estuarine fish. Fish Res Bull West Aust 7:1-13

Thomson, JM (1959) Some aspects of the ecology of Lake Macquarie, NSW, with regard to an alleged depletion of fish. IX. The fishes and their food. Aust J mar Freshwat Res 10:365-374

Trites RW (1983) Physical oceanographic features and processes relevant to Illex illecebrosus spawning in the western north Atlantic and subsequent larval distribution. NAFO Sci Coun Stud 6:39-55

Turgan G (1959) Recherches préliminaires sur la biologie des Temnodon saltator (tassergal) qui font leur migration par les détroits des Dardanelles et du Bosphore. Int Comm Sci Explor Medit Sea 15:409-420

van der Elst R (1976) Game fish of the east coast of southern Africa. I. The biology of the elf, Pomatomus saltatrix (Linnaeus), in the coastal waters of Natal. Investl Rep Oceanogr Res Inst 44:1-59

Vouglitois JJ, Able KW, Kurtz RJ, Tighe KA (1987) Life history and population dynamics of the bay anchovy in New Jersey. Trans Am Fish Soc 116:141-153

Walters CJ, Juanes F (1993) Recruitment limitation as a consequence of natural selection for use of restricted feeding habitats and predation risk taking by juvenile fishes. Can J Fish aquat Sci 50:2058-2070

Walters CJ, Stocker M, Tyler AV, Westrheim SJ (1986) Interaction between Pacific cod (Gadus macrocephalus) and herring (Clupea harengus pallasi) in the Hecate Strait,

This article was presented by C. Levings (Senior Editorial Advisor), Vancouver, British Columbia, Canada
British Columbia. Can J Fish Aquat Sci 43:830-837

Webb PW (1986) Locomotion and predator-prey relationships. In: Feder ME, Lauder GV (eds) Predator-prey relationships: perspectives and approaches from the study of lower vertebrates. University of Chicago Press, Chicago, p $24-41$

Weinstein MP (ed) (1988) Larval fish and shellfish transport through inlets. Am Fish Soc Symp 3, Bethesda

Werner EE, Gilliam JF (1984) The ontogenetic niche and species interactions in size-structured populations. A Rev Ecol Syst 15:393-425

Wicker AM, Johnson WE (1987) Relationships among fat content, condition factor, and first-year survival of Florida largemouth bass. Trans Am Fish Soc 116: $264-271$

Wilk SJ (1982) Weakfish, Cynoscion regalis. In: Grosslein MD. Azarovitz TR (eds) MESA New York Bight atlas monograph 15. Sea Grant Institute, Albany, p 91-92

Wilson DS (1975) The adequacy of body size as a niche difference. Am Nat 109:769-784

Yan HY (1987) Comparative reproductive strategies of the grass shrimps, Palaemonetes vulgaris and $P$. pugio (Decapoda, Natantia) in Great Sippewissett salt marsh, Massachusetts, USA. Crustaceana 52:141-148

Zar JH (1984) Biostatistical analysis. Prentice-Hall, Englewood Cliffs, NJ

Zastrow CE, Houde ED, Morin LG (1991) Spawning, fecundity, hatch-date frequency and young-of-the-year growth of bay anchovy Anchoa mitchilli in mid-Chesapeake Bay Mar Ecol Prog Ser 73:161-171

Zijlstra JJ (1988) Fish migrations between coastal and offshore areas. In: Jansson BO (ed) Coastal-offshore ecosystem interactions. Lecture notes on coastal and estuarine studies, 22. Springer-Verlag, Berlin, p 257-272

Manuscript first received: June 20,1994

Revised version accepted: May 15, 1995 